\title{
The nonlinear effect of somatic cell count on milk composition, coagulation properties, curd firmness modeling, cheese yield, and curd nutrient recovery
}

\author{
T. Bobbo, C. Cipolat-Gotet, G. Bittante, and A. Cecchinato ${ }^{1}$ \\ Department of Agronomy, Food, Natural Resources, Animals and Environment (DAFNAE), University of Padova, Viale dell'Università 16, \\ 35020 Legnaro (PD), Italy
}

\begin{abstract}
The aim of this study was to investigate the relationships between somatic cell count (SCC) in milk and several milk technological traits at the individual cow level. In particular, we determined the effects of very low to very high SCC on traits related to (1) milk yield and composition; (2) coagulation properties, including the traditional milk coagulation properties (MCP) and the new curd firming model parameters; and (3) cheese yield and recovery of milk nutrients in the curd (or loss in the whey). Milk samples from 1,271 Brown Swiss cows from 85 herds were used. Nine coagulation traits were measured: 3 traditional MCP [rennet coagulation time (RCT, min), curd firming rate $\left(\mathrm{k}_{20}, \mathrm{~min}\right)$, and curd firmness after $\left.30 \mathrm{~min}\left(\mathrm{a}_{30}, \mathrm{~mm}\right)\right]$ and 6 new curd firming and syneresis traits [potential asymptotic curd firmness at infinite time $\left(\mathrm{CF}_{\mathrm{P}}, \mathrm{mm}\right)$, curd firming instant rate constant $\left(\mathrm{k}_{\mathrm{CF}}, \% \times \min ^{-1}\right)$, syneresis instant rate constant $\left(\mathrm{k}_{\mathrm{SR}}, \% \times \min ^{-1}\right)$, rennet coagulation time estimated using the equation $\left(\mathrm{RCT}_{\mathrm{eq}}, \mathrm{min}\right)$, maximum curd firmness achieved within $45 \mathrm{~min}\left(\mathrm{CF}_{\max }, \mathrm{mm}\right)$, and time at achievement of $\left.\mathrm{CF}_{\max }\left(\mathrm{t}_{\max }, \min \right)\right]$. The observed cheese-making traits included 3 cheese yield traits $\left(\% \mathrm{CY}_{\mathrm{CURD}}, \% \mathrm{CY}_{\text {SOLIDS }}\right.$, and $\% \mathrm{CY}_{\text {WATER }}$, which represented the weights of curd, total solids, and water, respectively, as a percentage of the weight of the processed milk) and 4 nutrient recoveries in the curd ( REC $_{\mathrm{FAT}}, \mathrm{REC}_{\text {PROTEIN }}, \mathrm{REC}_{\text {SOLIDS }}$, and $\mathrm{REC}_{\text {ENERGY }}$, which each represented the percentage ratio between the nutrient in the curd and milk). Data were analyzed using a linear mixed model with the fixed effects of days in milk, parity, and somatic cell score (SCS), and the random effect of herd-date. Somatic cell score had strong influences on casein number and lactose, and also affected $\mathrm{pH}$; these were traits characterized by a quadratic pattern of the data. The results also showed a negative linear relationship between SCS and milk
\end{abstract}

Received October 11, 2015.

Accepted March 15, 2016.

${ }^{1}$ Corresponding author: alessio.cecchinato@unipd.it yield. Somatic cell score influenced almost all of the tested coagulation traits (both traditional and modeled), with the exceptions of $\mathrm{k}_{20}, \mathrm{CF}_{\mathrm{P}}$, and $\mathrm{k}_{\mathrm{SR}}$. Gelation was delayed when the SCS decreased (slightly) and when it increased (strongly) with respect to a value of 2 , as confirmed by the quadratic patterns observed for both RCT and $\mathrm{RCT}_{\text {eq }}$. The SCS effect on $\mathrm{a}_{30}$ showed a quadratic pattern almost opposite to that observed for $\mathrm{RCT}$. With respect to the $\mathrm{CF}_{\mathrm{t}}$ parameters, $\mathrm{k}_{\mathrm{CF}}$ decreased linearly as SCS increased, resulting in a linear decrease of $\mathrm{CF}_{\max }$ and a quadratic pattern for $\mathrm{t}_{\max }$. Milk SCS attained significance for $\% \mathrm{CY}_{\mathrm{CURD}}, \% \mathrm{CY}_{\text {WATER}}$,

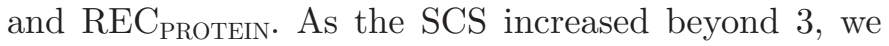
observed a progressive quadratic decrease of the water retained in the curd (\% $\left.\mathrm{CY}_{\text {WATER }}\right)$, which caused a parallel decrease in $\% \mathrm{CY}_{\text {CURD. }}$ With respect to $\mathrm{REC}_{\text {PROTEIN }}$ the negative effect of SCS was almost linear. Recovery of fat and (consequently) $\mathrm{REC}_{\text {ENERGY }}$ was characterized by a more evident quadratic trend, with the most favorable values associated with an intermediate SCS. Together, our results confirmed that high SCS has a negative effect on milk composition and technological traits, highlighting the nonlinear trends of some traits across the different classes of SCS. Moreover, we report that a very low SCS has a negative effect on some technological traits of milk.

Key words: somatic cell count, milk coagulation property, curd firming, cheese yield, whey loss

\section{INTRODUCTION}

The consumption of milk and dairy products is growing worldwide (International Dairy Federation, 2013), making increased milk production a key dairy breeding goal in recent decades (VanRaden, 2004; Miglior et al., 2005). However, selection for higher milk production has led to deteriorations of milk quality and cow welfare (Oltenacu and Broom, 2010). For instance, unfavorable genetic correlations between milk yield and diseases (e.g., mastitis and ketosis) have been reported (Ingvartsen et al., 2003). Bovine mastitis is one of the most economically important diseases in dairy herds; 
the consequent high SCC, which is measured as a standard indicator trait of udder health and milk quality, reduces the price paid for milk (Seegers et al., 2003; Viguier et al., 2009). Moreover, milk with a high cell count is reported to have lower casein (Haenlein et al., 1973; Auldist and Hubble, 1998) and lactose (Kitchen, 1981; Auldist and Hubble, 1998) contents, due to increased proteinase-mediated degradation and decreased biosynthesis, respectively. The influence of SCC on fat concentration is more controversial; although some authors (Harmon, 1994; Schallibaum, 2001) found lower values due to reduced synthetic activity of the mammary gland, others observed a higher fat content due to a reduced milk volume (Shuster et al., 1991; Bruckmaier et al., 2004).

Alterations in the chemical composition of high-SCC milk make it less suitable for consumption and cheese processing, with the latter issue reflecting slower coagulation, weak consistency of the curd, and reduced cheese yield (Barbano et al., 1991; Auldist and Hubble, 1998). The technological quality of the milk used in cheese making is commonly evaluated by measuring milk coagulation properties (MCP; Annibaldi et al., 1977; McMahon and Brown, 1982) with computerized renneting meters. The 3 traditional parameters that define the clotting ability of milk, and that can be measured by mechanical lactodynamograph (Formagraph; Foss Electric A/S, Hillerød, Denmark), are rennet coagulation time (RCT, min), curd-firming time $\left(\mathbf{k}_{\mathbf{2 0}}, \mathrm{min}\right)$, and firmness of the curd at $30 \mathrm{~min}$ after the addition of rennet $\left(\mathbf{a}_{\mathbf{3 0}}, \mathbf{m m}\right)$. An association between elevated SCC and an increase in RCT has been observed by different authors (Ng-Kwai-Hang et al., 1989; Barłowska et al., 2009).

The large majority of relevant published studies have included SCC as a linear covariate in the model, or compared the results obtained using milk with "normal" versus "high" SCC. In these studies, when several classes of SCC are used, they normally do not include classes $<100,000$ cells $/ \mathrm{mL}$, so the detailed effects of very low to very high SCC on milk technological traits have not been fully studied.

Recent studies introduced the strategy of prolonging the observation time and modeling curd firmness (CF) using new time $\left(\mathbf{C F}_{\mathbf{t}}\right)$ parameters (Bittante, 2011; Cipolat-Gotet et al., 2012; Bittante et al., 2013). Milk coagulation properties are of interest for 2 main reasons: first, they have technological value for optimizing the cheese-making process and predicting possible abnormalities both during the process and in the final product; and second, they may be used to indirectly predict cheese yield (CY) through their relationships with losses of fines in whey and with moisture retained in the curd. This second aspect is important because
MCP are relatively easy to measure in multiple samples at the laboratory level, whereas direct measurements of CY and nutrient recovery traits are expensive and time-consuming.

Given the complexity of cheese making, the fat and protein contents of milk have frequently been used as proxies for measuring CY. However, the efficiency of the cheese-making process is better defined by the recoveries of milk components in the curd and their losses in the whey (Banks, 2007). More recently, percentage cheese yield (\%CY) and nutrient recovery (REC) of individual milk samples have been analyzed using a model cheese-making procedure developed by CipolatGotet et al. (2013), which mimics all phases of cheese production. However, there is little information available regarding the relationships between technological traits of milk and SCC.

Even if bulk tank milk is used for cheese production, information at the cow level might be useful in order to include milk technological traits as breeding goals in dairy cows. Moreover, the individual variation, which is higher compared with that of bulk samples, helps to clarify the relationships between milk SCC and cheesemaking traits. Therefore, the aim of this study was to elucidate the relationship between SCC and milk quality and technological traits at the individual cow level. In particular, we performed a detailed investigation of the effects of a range of SCC (from very low to very high) on (1) the milk yield and composition (i.e., fat, protein, casein, casein number, lactose, urea, and $\mathrm{pH})$; (2) the coagulation properties (traditional MCP and the new CF model parameters); and (3) the cheese yield and recovery of milk nutrients in the curd and loss in the whey.

\section{MATERIALS AND METHODS}

\section{Milk Sample Collection}

This study is part of the Cowability-Cowplus Projects, which were described in detail by Cipolat-Gotet et al. (2013) and Cecchinato et al. (2013). Briefly, individual milk samples of 1,271 Brown Swiss cows were collected once from 85 herds (a maximum of 15 cows/ herd, 1 or 2 herds per week, 13 mo in total) located in Trento Province, northern Italy. The relevant environmental conditions were described in detail by Sturaro et al. (2013). The milk samples (one per cow) were collected during the evening milking. After collection, each sample was divided into 2 subsamples, which were refrigerated $\left(4^{\circ} \mathrm{C}\right.$, without preservative). One subsample $(50 \mathrm{~mL})$ was transferred to the Milk Quality Laboratory of the Breeders Federation of Trento Province (Trento, Italy) for milk composition analysis. The other $(2,000$ 
$\mathrm{mL}$ ) was transferred to the Cheese-Making Laboratory of the Department of Agronomy, Food, Natural Resources, Animals and Environment (DAFNAE) at the University of Padova (Legnaro, Padova, Italy) for MCP analysis and model cheese making. Data on herds and cows were provided by the Breeders Federation of Trento Province and the Superbrown Consortium (Italy).

\section{Analysis of Quality Traits, MCP, CF Modeling, Cheese Yield, and Whey Losses}

Milk Composition Traits. In the Milk Quality Laboratory in Trento (Italy), each milk subsample was analyzed within $20 \mathrm{~h}$ of milking for fat, protein, casein, lactose (\%), and urea $(\mathrm{mg} / 100 \mathrm{~g})$ using a Milkoscan FT6000 (Foss Electric A/S), calibrated according to the following reference methods: fat (ISO, 2010b; ISO 1211|IDF 1; gravimetric method, Rose-Gottlieb); protein (ISO, 2014; ISO 8968-1|IDF 20-1; titrimetric method, Kjeldahl); casein (ISO, 2004a; ISO 17997-1|IDF 29; titrimetric method, Kjeldahl); lactose (ISO, 2002; ISO 5765-1|IDF 79-1; enzymatic method); urea (ISO, 2004b; ISO 14637|IDF 195; differential pH method); TS (ISO, 2010a; ISO 6731|IDF 21; determination of TS content). Ten reference milk samples per month (Italian Breeders Association, Rome, Italy) were used for adjusting calibrations, and 1 repeated sample every 50 analyzed samples was used to control repeatability of analyses.

Milk $\mathrm{pH}$, adjusted for sample temperature, was measured using a Crison Basic 25 electrode (Crison Instruments SA, Barcelona, Spain). Each SCC was obtained with a Fossomatic FC counter (Foss Electric A/S) and log-transformed to an SCS (Ali and Shook, 1980). Bacterial count was not measured on individual milk samples.

Traditional MCP. In the cheese-making laboratory of the University of Padova (Italy), within $20 \mathrm{~h}$ of milking, the time from rennet addition to milk gelation (RCT, min), curd-firming rate (min to a curd firmness of $20 \mathrm{~mm} ; \mathrm{k}_{20}$ ) and curd firmness after $30 \mathrm{~min}$ from rennet addition $\left(\mathrm{a}_{30}\right.$, in $\left.\mathrm{mm}\right)$ were determined using a mechanical lactodynamograph (Formagraph; Foss Electric A/S). The duration of the test was extended to 90 min, so that almost all $(99.7 \%)$ of the milk samples coagulated and yielded $\mathrm{k}_{20}$ values. The details of the experimental conditions (e.g., temperature of the milk samples, concentration and type of rennet) were as reported in Cipolat-Gotet et al. (2012).

New Curd Firming and Syneresis Traits. For each milk sample, 360 curd firmness values were recorded ( 1 every $15 \mathrm{~s}$ for $90 \mathrm{~min}$ ). The new parameters of curd firmness modeled on time $t\left(C F_{t}\right)$ were estimated using the 4-parameter model proposed by Bittante et al. (2013):

$$
C F_{t}=C F_{P} \times\left(1-e^{-k_{C F} \times\left(t-R C T_{e q}\right)}\right) \times e^{-k_{S R} \times\left(t-R C T_{e q}\right)},
$$

where $C F_{t}(\mathrm{~mm})$ is the curd firmness at time $t ; C F_{P}$ $(\mathrm{mm})$ is the maximum asymptotic curd firmness; $k_{C F}$ $\left(\% \times \min ^{-1}\right)$ is the curd-firming instant rate constant; $k_{S R}\left(\% \times \min ^{-1}\right)$ is the curd syneresis instant rate constant; and $R C T_{e q}(\mathrm{~min})$ is the rennet coagulation time. Moreover, 2 additional traits related to maximum curd firmness (MCF) were calculated: the maximum $C F_{t}$ value $\left(\boldsymbol{C F}_{\text {max }}, \mathrm{mm}\right)$ and time at $\mathrm{CF}_{\max }\left(\boldsymbol{t}_{\text {max }}, \min \right)$.

Individual Cheese Yield and Curd Nutrient Recovery. These phenotypes were obtained through a model cheese-making procedure performed on a milk subsample $(1,500 \mathrm{~mL})$ from each individual cow. Cheese yield was assessed using 7 components that formed 2 groups of traits: (1) $3 \% \mathrm{CY}$ traits that expressed the weights of the fresh curd $\left(\mathbf{\%}_{\mathbf{C Y}} \mathbf{Y U R D}_{\mathbf{C U R}}\right)$, the curd DM (\% $\left.\mathbf{C Y}_{\text {Solids }}\right)$, and the water retained in the curd $\left(\mathbf{\%} \mathbf{C Y} \mathbf{Y}_{\text {WATER }}\right)$ as percentages of the weight of the processed milk; and (2) 4 REC traits representing the proportions of milk nutrients and energy retained in the curd $\left(\mathbf{R E C}_{\text {SOLIDS }}, \mathbf{R E C}_{\mathrm{FAT}}, \mathbf{R E C}_{\text {PROTEIN }}\right.$, and RE$\mathbf{C}_{\text {ENERGY }}$, calculated as the percentage ratios between a given component in the curd versus the processed milk). The energy within the curd was calculated as the difference between the energy in the milk and in the whey (NRC, 2001). A detailed description of the individual model cheese-making procedure used to obtain the phenotypes analyzed in this study, as well as the relevant sources of phenotypic variation, can be found in Cipolat-Gotet et al. (2013). Finally, all analyses (milk composition, coagulation, and cheese-making traits) were performed within $20 \mathrm{~h}$ from milk collection.

\section{Statistical Analysis}

Data were analyzed using the MIXED procedure of SAS (SAS Institute Inc., Cary, NC) with the following linear model:

$$
\begin{aligned}
\mathrm{y}_{i j k l m}= & \mu+\mathrm{DIM}_{i}+\text { Parity }_{j}+\mathrm{SCS}_{k} \\
& + \text { Herd-date }_{l}+e_{i j k l m},
\end{aligned}
$$

where $\mathrm{y}_{i j k l m}$ is the observed trait; $\mu$ is the overall mean; $\mathrm{DIM}_{i}$ is the fixed effect of the $i$ th class of days in milk $[i=6$ classes: class $1 \leq 60(\mathrm{n}=178) ; 60<$ class $2 \leq 120$ $(\mathrm{n}=265) ; 120<$ class $3 \leq 180(\mathrm{n}=226) ; 180<$ class $4 \leq 240(\mathrm{n}=167) ; 240<$ class $5 \leq 300(\mathrm{n}=176) ;$ class 
$6>300(\mathrm{n}=188)]$ Parity $_{j}$ is the fixed effect of the $j$ th parity $[j=1(\mathrm{n}=368) ; 2(\mathrm{n}=362) ; 3(\mathrm{n}=201) ; 4(\mathrm{n}$ $=144) ; \geq 5(\mathrm{n}=186)] ; \mathrm{SCS}_{k}$ is the fixed effect of the $k$ th class of SCS $[k=1$ to 7 ; class $1 \leq 0.66(\mathrm{n}=131)$; $0.66<$ class $2 \leq 1.59(\mathrm{n}=193) ; 1.59<$ class $3 \leq 2.52$ $(\mathrm{n}=215) ; 2.52<$ class $4 \leq 3.45(\mathrm{n}=224) ; 3.45<$ class $5 \leq 4.38(\mathrm{n}=210) ; 4.38<$ class $6 \leq 5.31(\mathrm{n}=137)$; class $7>5.31(\mathrm{n}=147)]$; Herd-date ${ }_{l}$ is the random effect of the $l$ th herd-date ( $l=1$ to 85$)$; and $e_{i j k l m}$ is the random residual. For the studied coagulation properties, cheese yield traits, and nutrient recoveries in curd, the pendulum/vat ${ }_{m}$ effect was added to the above-described model as the fixed effect of the $m$ th pendulum $(m=1$ to 10$)$ for coagulation properties or the $m$ th number of the vat or waterbath $(m=1$ to 15$)$ for cheese yield and nutrient recoveries. Herd-date and residuals were assumed to be normally distributed with a mean of zero and variances of $\sigma_{h}^{2}$ and $\sigma_{e}^{2}$, respectively. The proportion of variance explained by herd-test date was calculated by dividing the corresponding variance component by the total variance.

Polynomial contrasts $(P<0.05)$ were estimated to look at the response curve of the data for the SCS effect; the first-order comparisons measured linear relationships, whereas the second- and third-order comparisons measured quadratic and cubic relationships, respectively.

\section{RESULTS}

\section{Descriptive Statistics}

As all the investigated traits were characterized by normal distributions (Cipolat-Gotet et al., 2012, 2013), only the 1st and 99th percentiles are provided in Table 1. The milk yield of the Brown Swiss cows reared in the different dairy farming systems averaged $24.2 \mathrm{~kg} / \mathrm{d}$ and showed a large variability $(\mathrm{CV}=31.7 \%)$. Among the milk composition traits, casein number and $\mathrm{pH}$ showed the lowest variabilities, with CV of 1.65 and $1.19 \%$, respectively. The other milk composition traits confirmed the good quality that characterizes milk of Brown Swiss cows and presented intermediate variabilities (from $3.7 \%$ for lactose to $31.4 \%$ for milk urea).

The SCS ranged from -0.47 (1st percentile) to 7.77 (99th percentile), corresponding to SCC of 9,000 and 2,722,000 cells/mL, respectively. Both SCS and SCC exhibited very high variabilities.

The mean values for RCT and $\mathrm{k}_{20}$ were 19.9 and 5.6 min, respectively, whereas $\mathrm{a}_{30}$ averaged $29.6 \mathrm{~mm}$. In the present work, the $\mathrm{CF}_{\mathrm{t}}$ parameters had mean values as follows: $20.9 \mathrm{~min}$ for the coagulation time calculated for each milk sample on the basis of all 360 data points $\left(\mathrm{RCT}_{\text {eq }}\right) ; 54.6 \mathrm{~mm}$ for the asymptotic potential curd firmness theoretically achievable at infinite time in absence of curd syneresis $\left(\mathrm{CF}_{\mathrm{P}}\right) ; 12.6 \% \times \mathrm{min}^{-1}$ for the instant rate constant of curd firming $\left(\mathrm{k}_{\mathrm{CF}}\right)$, leading the $\mathrm{CF}_{\mathrm{t}}$ curve toward a value of $\mathrm{CF}_{\mathrm{P}}$ shortly after $\mathrm{RCT}$; and $1.39 \% \times \mathrm{min}^{-1}$ for the instant rate constant of syneresis, leading $\mathrm{CF}_{\mathrm{t}}$ toward zero over an extended duration $\left(\mathrm{k}_{\mathrm{SR}}\right)$. On average, the maximum $\mathrm{CF}$ value $\left(\mathrm{CF}_{\max }\right)$ was $36.5 \mathrm{~mm}$, and it was achieved $\left(\mathrm{t}_{\max }\right) 41.5$ min after rennet addition.

The mean $\% \mathrm{CY}_{\mathrm{CURD}}$, which corresponded to the sum of $\% \mathrm{CY}_{\text {SOLIDS }}$ and $\% \mathrm{CY}_{\text {WATER }}$, was $15 \%$. The curd nutrient recovery was, on average, close to the mean casein number for protein, almost $90 \%$ for fat, slightly more than half for total solids, and about two-thirds for milk energy (Table 1).

\section{Sources of Variation Among Quality Traits}

The results of our ANOVA for the milk yield and composition traits are summarized in Table 2. The proportion of variance explained by herd-test date was more than $70 \%$ for urea; approximately $50 \%$ for milk production, casein number, and $\mathrm{pH} ; 20 \%$ for fat, protein, and casein contents and fat:protein ratio; and slightly more than $10 \%$ for lactose and SCS. As expected, DIM and parity effects played important roles in explaining the variation of almost all considered traits, with the exceptions of fat, fat:protein, and urea traits, for which parity had a negligible effect. Detailed information on the effect of DIM and parity on the investigated traits was reported by Cipolat-Gotet et al. (2012, 2013) and Bittante et al. (2015). The influence of DIM and parity was tested also on milk SCS (Table 2) and the results showed an increase in SCS with advancing age and stage of lactation (data not shown).

In the present study, we focused on the effect of SCS, which had strong influences on casein number and lactose, and also affected $\mathrm{pH}$ and urea. The results of the polynomial contrasts are reported in Table 2 . The least squares means (LSM) and the corresponding standard errors of the milk yield and composition traits for which SCS had significant effects are presented in Figure 1, together with the corresponding curve of the data across the different classes of SCS (according to the obtained significant linear or quadratic contrasts). Even though the ANOVA did not reveal a significant effect of SCS on milk yield (Table 2), the contrasts showed a negative linear relationship $(P<0.05)$ between these 2 traits (Figure 1a). Milk fat, protein, and casein contents were not affected by milk SCS. Urea exhibited an erratic trend across the SCS classes and was characterized by a high standard error of the means (Figure 1d). The casein number and lactose showed clear quadratic patterns: their LSM remained relatively constant across 
Table 1. Descriptive statistics of single test-day milk yield, composition, traditional milk coagulation properties $(\mathrm{MCP})$, curd firming, cheese yield (\%CY), and curd nutrient recovery $(\mathrm{REC})^{1}$

\begin{tabular}{|c|c|c|c|c|c|}
\hline Trait $^{2}$ & $\mathrm{~N}^{3}$ & Mean & $\mathrm{SD}$ & $\mathrm{P} 1$ & P99 \\
\hline Milk yield, kg/d & 1,233 & 24.2 & 7.7 & 8.5 & 44.8 \\
\hline \multicolumn{6}{|l|}{ Milk composition } \\
\hline Fat, $\%$ & 1,242 & 4.20 & 0.65 & 2.71 & 5.86 \\
\hline Protein, \% & 1,250 & 3.70 & 0.42 & 2.86 & 4.70 \\
\hline Fat:protein & 1,239 & 1.14 & 0.18 & 0.74 & 1.62 \\
\hline Casein, \% & 1,250 & 2.89 & 0.32 & 2.26 & 3.65 \\
\hline Casein number, \% & 1,246 & 77.1 & 1.3 & 73.9 & 79.9 \\
\hline Lactose, $\%$ & 1,246 & 4.86 & 0.18 & 4.36 & 5.22 \\
\hline Urea, mg/100 g & 1,252 & 25.9 & 8.1 & 9.0 & 45.2 \\
\hline $\mathrm{pH}$ & 1,248 & 6.64 & 0.08 & 6.45 & 6.83 \\
\hline $\mathrm{SCC}, 10^{3} / \mathrm{mL}$ & 1,257 & 252 & 615 & 9 & 2,722 \\
\hline SCS, units & 1,257 & 2.98 & 1.86 & -0.47 & 7.77 \\
\hline \multicolumn{6}{|l|}{ Traditional MCP } \\
\hline $\mathrm{RCT}, \min$ & 1,253 & 19.9 & 5.7 & 10.3 & 38.3 \\
\hline $\mathrm{k}_{20}, \min$ & 1,241 & 5.62 & 3.59 & 2.00 & 19.30 \\
\hline $\mathrm{a}_{30}, \mathrm{~mm}$ & 1,192 & 29.6 & 11.0 & 0.7 & 50.8 \\
\hline \multicolumn{6}{|l|}{ Curd firming } \\
\hline $\mathrm{RCT}_{\mathrm{eq}}, \min$ & 1,250 & 20.9 & 6.4 & 11.1 & 41.1 \\
\hline $\mathrm{CF}_{p}, \mathrm{~mm}$ & 1,141 & 54.6 & 13.9 & 26.1 & 97.9 \\
\hline $\mathrm{k}_{\mathrm{CF}}, \% \times \min ^{-1}$ & 1,155 & 12.6 & 5.7 & 2.4 & 28.4 \\
\hline $\mathrm{k}_{\mathrm{SR}}, \% \times \min ^{-1}$ & 1,153 & 1.39 & 0.56 & 0.15 & 2.95 \\
\hline $\mathrm{CF}_{\max }, \mathrm{mm}$ & 1,248 & 36.5 & 7.3 & 18.5 & 53.4 \\
\hline $\mathrm{t}_{\max }, \min$ & 1,226 & 41.5 & 12.0 & 22.4 & 81.4 \\
\hline \multicolumn{6}{|l|}{ Cheese yield (\%CY) } \\
\hline$\% \mathrm{CY}_{\mathrm{CURD}}$ & 1,247 & 15.0 & 1.9 & 11.0 & 19.6 \\
\hline$\% \mathrm{CY}_{\text {SOLIDS }}$ & 1,238 & 7.22 & 0.94 & 5.37 & 9.93 \\
\hline$\% \mathrm{CY}_{\text {WATER }}$ & 1,241 & 7.80 & 1.28 & 5.04 & 11.23 \\
\hline \multicolumn{6}{|c|}{ Nutrient recovery (REC) } \\
\hline REC $_{\text {PROTEIN }}, \%$ & 1,242 & 78.1 & 2.4 & 72.4 & 83.3 \\
\hline $\mathrm{REC}_{\mathrm{FAT}}, \%$ & 1,231 & 89.9 & 3.6 & 78.7 & 95.9 \\
\hline REC $_{\text {SOLIDS }}, \%$ & 1,244 & 52.1 & 3.6 & 44.1 & 60.9 \\
\hline REC $_{\text {ENERGY }}, \%$ & 1,231 & 67.3 & 3.3 & 59.2 & 75.1 \\
\hline
\end{tabular}

${ }^{1} \mathrm{P} 1=1$ st percentile; $\mathrm{P} 99=99$ th percentile.

${ }^{2} \mathrm{SCS}=\log _{2}(\mathrm{SCC} / 100,000)+3 ; \mathrm{RCT}=$ rennet coagulation time; $\mathrm{k}_{20}=$ curd firming rate as minutes to a curd firmness of $20 \mathrm{~mm} ; \mathrm{a}_{30}=$ curd firmness after $30 \mathrm{~min}$ from rennet addition; $\mathrm{RCT}_{\mathrm{eq}}=$ rennet coagulation time estimated using the equation; $\mathrm{CF}_{\mathrm{P}}=$ potential asymptotic curd firmness at infinite time; $\mathrm{k}_{\mathrm{CF}}=$ curd firming instant rate constant; $\mathrm{k}_{\mathrm{SR}}=$ syneresis instant rate constant; $\mathrm{CF}_{\max }=$ maximum curd firmness achieved within $45 \mathrm{~min} ; \mathrm{t}_{\max }=$ time at achievement of $\mathrm{CF}_{\max } ; \% \mathrm{CY}_{\mathrm{CURD}}=$ fresh cheese yield; $\% \mathrm{CY}_{\text {SOLIDS }}=$ total solids cheese yield; $\% \mathrm{CY}_{\mathrm{WATER}}=$ water entrapped in the curd; $\mathrm{REC}_{\mathrm{PROTEIN}}, \%=$ protein retention; $\mathrm{REC}_{\mathrm{FAT}}, \%=$ fat retention; $\mathrm{REC}_{\text {SOLIDS }}, \%=$ total solids retention; $\mathrm{REC}_{\text {ENERGY }}, \%=$ energy retention.

${ }^{3}$ Number of samples.

the first 3 classes of SCS, and then decreased almost linearly as the SCS increased beyond 2 (Figures $1 \mathrm{~b}$ and 1c). Finally, although the LSM differences for milk $\mathrm{pH}$ were modest, decreases in lactose and the casein number were accompanied by decreases in milk acidity (Figure 1e).

\section{Sources of Variation Among MCP and CF Modeling}

The results from our statistical analysis of the various coagulation properties are summarized in Table 3. Notably, the proportion of variance explained by herd-test date was lower for the coagulation properties than for the quality traits and was much lower than for milk yield; the values for coagulation properties ranged between $\sim 4$ and $16 \%$, with the exception of $t_{\max }(22 \%)$. As expected, DIM had strong influences on both the traditional $\mathrm{MCP}$ and the new $\mathrm{CF}_{\mathrm{t}}$ model parameters. Parity was significant $(P<0.05)$ in explaining the variation of only RCT among the traditional traits, but it was significant for all of the $\mathrm{CF}_{\mathrm{t}}$ traits (with the exception of $\mathrm{CF}_{\mathrm{P}}$ ).

The effect of pendulum, which was the only effect related to instrument repeatability, was confirmed to play important roles in explaining the variation of all traits except for $\mathrm{RCT}$ and $\mathrm{RCT}_{\mathrm{eq}}$. Somatic cell score influenced almost all of the tested coagulation traits, both traditional and modeled, with the only exceptions being $\mathrm{k}_{20}, \mathrm{CF}_{\mathrm{P}}$, and $\mathrm{k}_{\mathrm{SR}}$.

The LSM of the coagulation traits affected by SCS are reported in Figure 2. The most rapid gelation was exhibited by milk samples with an SCS in the class centered on a value of 2 , both when expressed as single point trait $(\mathrm{RCT})$ or as a $\mathrm{CF}_{\mathrm{t}}$ equation parameter 
$\left(\mathrm{RCT}_{\mathrm{eq}}\right)$. Gelation was delayed when SCS decreased (slightly) or increased (strongly) with respect to the class centered on an SCS of 2, as confirmed by the quadratic patterns observed for both $\mathrm{RCT}$ and $\mathrm{RCT}_{\text {eq }}$. Considering the curd firming process, within the traditional MCP, SCS did not show any significant effect on $\mathrm{k}_{20}$, whereas the effect on $\mathrm{a}_{30}$ seemed to be opposite to that seen for RCT (Figure 2b). In the case of the $\mathrm{CF}_{\mathrm{t}}$ parameters, $\mathrm{CF}_{\mathrm{P}}$ and $\mathrm{k}_{\mathrm{SR}}$ were not affected, but $\mathrm{k}_{\mathrm{CF}}$ decreased linearly as SCS increased (Figure 2d). This yielded a linear decrease of $\mathrm{CF}_{\max }$ (Figure 2e) and a quadratic pattern for $t_{\max }$, which exhibited a relevant delay only when SCS exceeded 3 (Figure 2f).

\section{Sources of Variation Among Cheese Yield and Whey Losses}

Table 4 shows the roles of the considered effects in explaining variations of the cheese yield traits and milk nutrient recovery in the curd. For these traits, the proportion of variance explained by herd-test date (20 to $40 \%$ ) was much greater than that seen for the coagulation and curd-firming traits. As expected, DIM was the most important source of variation affecting all of the studied the traits. Parity had a strong influence on $\% \mathrm{CY}_{\mathrm{WATER}}$ and (consequently) $\% \mathrm{CY}_{\mathrm{CURD}}$, and affected $\mathrm{REC}_{\text {PROTEIN. Unlike the coagulation and curd firming }}$ traits, the effects of the instruments used (waterbaths and individual vats) were negligible in explaining the variations of the cheese yield and curd recovery traits. Similar to parity, SCS attained significance exclusively for $\% \mathrm{CY}_{\mathrm{CURD}}, \% \mathrm{CY}_{\text {WATER }}$, and $\mathrm{REC}_{\text {PROTEIN }}$.

Figure 3 depicts the LSM results for cheesemakingrelated traits across the different classes of SCS. All of the affected traits showed nonlinear effects for SCS. As SCS increased beyond 3, there was a progressive decrease in water retained in the curd (decreasing $\% \mathrm{CY}_{\text {WATER }}$; Figure $3 \mathrm{~b}$ ), which caused a parallel decrease in $\% \mathrm{CY}_{\text {CURD }}$ (Figure 3a). For REC $\mathrm{R}_{\text {PROTEIN }}$, the negative effect of SCS was almost linear (Figure 3c). In contrast, $\mathrm{REC}_{\mathrm{FAT}}$ (Figure 3d) and (consequently) $\mathrm{REC}_{\text {ENERGY }}$ (Figure 3e) showed more evident quadratic trends, with the most favorable values being observed for milk with an intermediate SCS content, whereas lower values were seen for milk samples with smaller and greater SCS.

\section{DISCUSSION}

\section{SCS Affects the Variation of Milk Yield and Composition}

An infection in the udder triggers an inflammatory response characterized by recruitment of white cells from the bloodstream and altered secretion of various molecules (Wellnitz and Bruckmaier, 2012). Because cell numbers in milk are associated with inflammation, SCC is recognized as the international standard indicator of udder health and milk quality (Sharif and Muhammad, 2008). Bovine mastitis increases the milk SCC, decreasing milk production and changing the composition of the milk (Kitchen, 1981; Le Maréchal et al., 2011). Inflammation damages the mammary gland tissue, inhibiting the biosynthesis of fat, protein, and lactose, and thereby decreasing milk yield (Harmon, 1994; Schallibaum, 2001). In the present study, we observed a negative linear relationship between milk production and the classes of SCS (Figure 1a), although

Table 2. Results from ANOVA ( $F$-value and significance) for single test-day milk yield and composition traits

\begin{tabular}{|c|c|c|c|c|c|c|c|c|}
\hline \multirow[b]{2}{*}{ Trait } & \multirow[b]{2}{*}{ DIM } & \multirow[b]{2}{*}{ Parity } & \multirow[b]{2}{*}{$\mathrm{SCS}^{1}$} & \multicolumn{3}{|c|}{ SCS Contrast } & \multirow[b]{2}{*}{ Herd-date, ${ }^{2} \%$} & \multirow[b]{2}{*}{$\mathrm{RMSE}^{3}$} \\
\hline & & & & Linear & Quadratic & Cubic & & \\
\hline Milk yield, kg/d & $118.4^{* * *}$ & $35.7^{* * *}$ & 1.5 & $4.2^{*}$ & 0.1 & 3.7 & 48.9 & 4.67 \\
\hline \multicolumn{9}{|l|}{ Milk composition } \\
\hline Fat, $\%$ & $14.4^{* * *}$ & 0.3 & 1.0 & 0.7 & 0.4 & 0.1 & 19.8 & 0.57 \\
\hline Protein, \% & $175.1^{* * *}$ & $8.2^{* * *}$ & 0.4 & 0.9 & 0.2 & 0.2 & 21.3 & 0.27 \\
\hline Fat:protein & $12.3^{* * *}$ & 2.3 & 0.6 & 0.5 & 0.0 & 0.0 & 17.0 & 0.16 \\
\hline Casein, $\%$ & $167.4^{* * *}$ & $12.0^{* * *}$ & 0.6 & 0.5 & 1.1 & 0.1 & 22.1 & 0.21 \\
\hline Casein number, \% & $4.5^{* * *}$ & $14.0 * * *$ & $13.5^{* * *}$ & $60.5^{* * *}$ & $8.1^{* *}$ & $4.3^{*}$ & 57.1 & 0.79 \\
\hline Lactose, $\%$ & $11.4^{* * *}$ & $21.2^{* * *}$ & $38.4^{* * *}$ & $198.6^{* * *}$ & $17.1^{* * *}$ & 1.2 & 10.5 & 0.14 \\
\hline Urea, mg/100 g & $4.9 * * *$ & 0.5 & $2.5^{*}$ & 2.6 & 0.1 & 0.0 & 72.9 & 4.26 \\
\hline $\mathrm{pH}$ & $5.5^{* * *}$ & $6.4^{* * *}$ & $3.6^{* *}$ & $12.4^{* * *}$ & $4.4^{*}$ & 0.7 & 50.8 & 0.06 \\
\hline SCS, units & $26.8^{* * *}$ & $16.7^{* * *}$ & - & - & - & - & 11.3 & 1.62 \\
\hline
\end{tabular}

${ }^{1} \mathrm{SCS}=\log _{2}(\mathrm{SCC} / 100,000)+3$.

${ }^{2}$ Herd-date effect expressed as proportion of variance explained by herd/test date calculated by dividing the corresponding variance component by the total variance.

${ }^{3} \mathrm{RMSE}=$ root mean square error.

${ }^{*} P<0.05 ;{ }^{* *} P<0.01 ;{ }^{* * *} P<0.001$. 
[a]

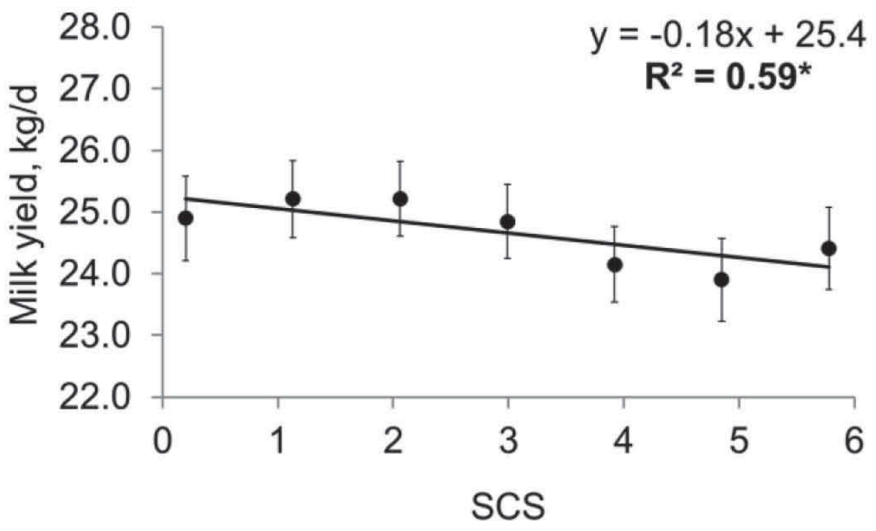

[c]

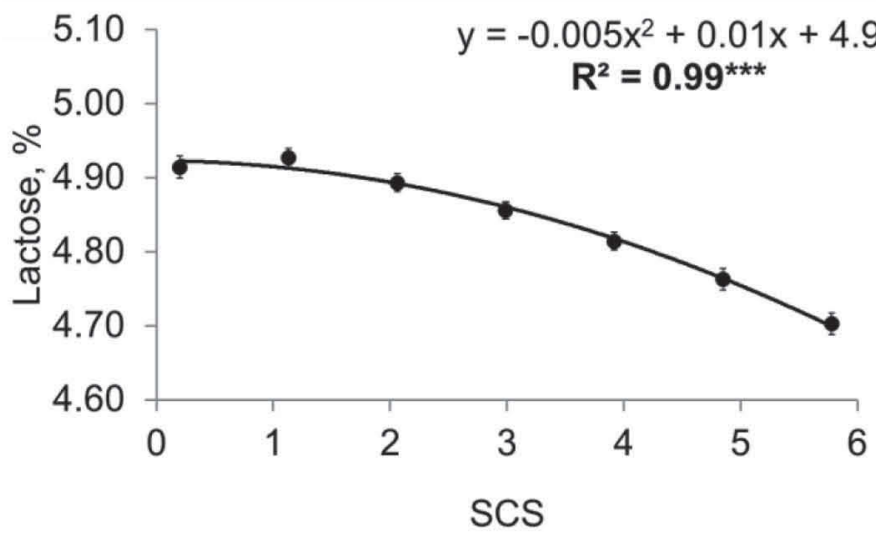

[e]

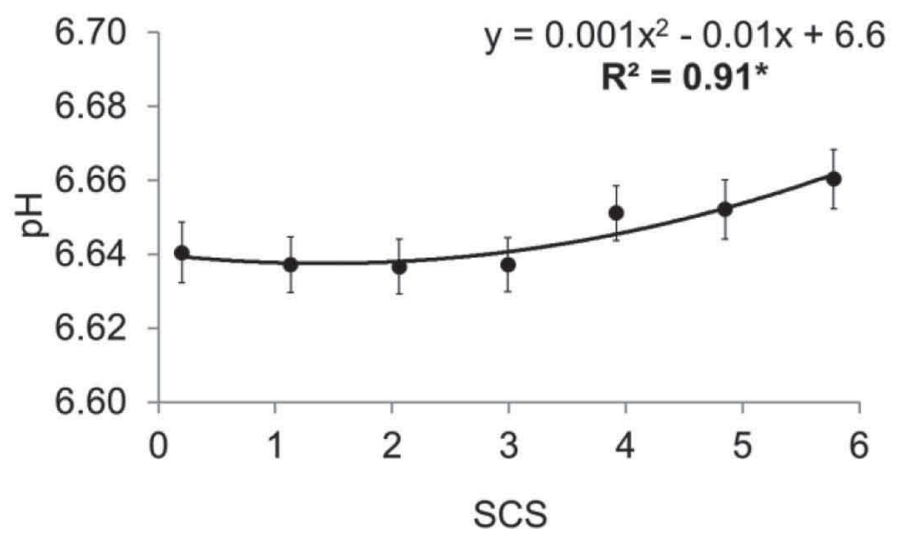

[b]

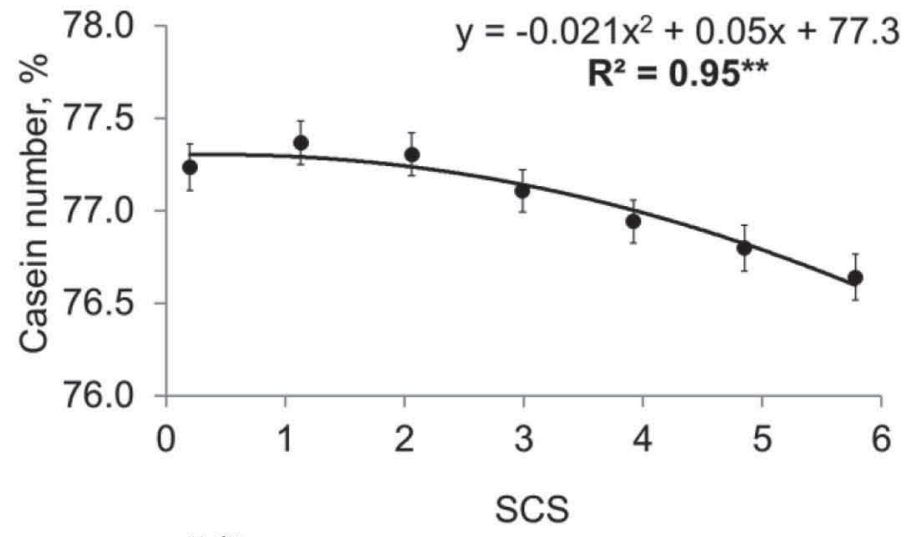

[d]

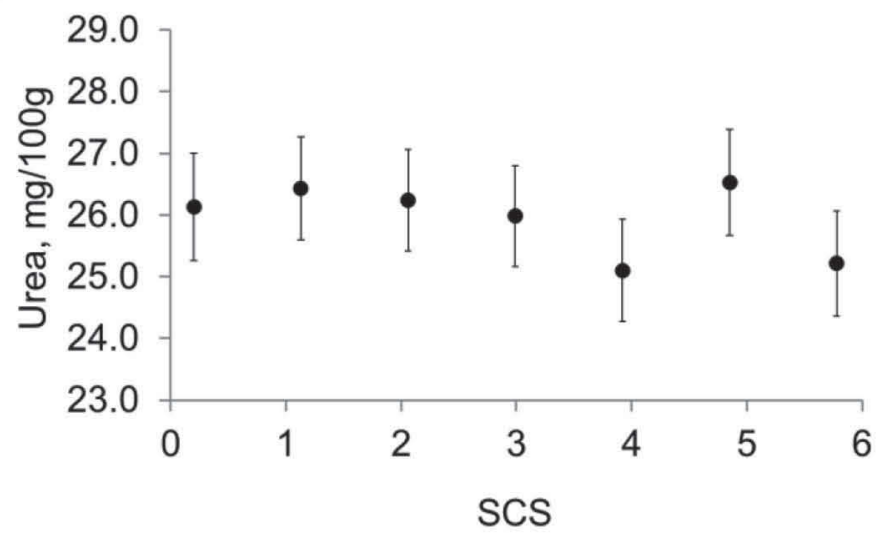

Figure 1. Least squares means of milk composition traits across SCS. Results of the polynomial contrasts have been reported: the response curve of the data across classes of SCS (linear or quadratic), the coefficient of determination $\left(\mathrm{R}^{2}\right)$ of the regression and the $P$-value of the polynomial contrasts. ${ }^{*} P<0.05 ;{ }^{*} P<0.01 ;{ }^{* * *} P<0.001$. Error bars correspond to SE of LSM.

the numeric pattern seemed slightly curvilinear. This trend agrees with the results obtained by Koldeweij et al. (1999), who found a linear relationship between $\log _{10}(\mathrm{SCC})$ and test-day milk yield. The same authors evaluated quadratic and cubic effects, but found that they contributed little to the overall fit of the models.
The linear relationship predicts that milk production will decrease by $2.04 \mathrm{~kg}$ for each unit increase in $\log _{10}(\mathrm{SCC})$, leading to a 10 -fold increase in SCC. This corresponds to a decrease of $0.6 \mathrm{~kg} / \mathrm{d}$ of milk per unit of increase in $\log _{2}(\mathrm{SCC})$, which corresponds to a 2 -fold increase in SCC. Our estimate $(-0.18 \mathrm{~kg} / \mathrm{d}$ per 
unit) is much smaller, even in the interval between SCS values of 2 and $5(-0.5 \mathrm{~kg} / \mathrm{d})$. However, it should be noted that we excluded any cow that showed signs of clinical mastitis. Previously, the relationships between repeated records of milk yield and the SCS of 33,453 first-lactation Norwegian Red cows were described by de los Campos et al. (2006) using equations that considered possible recursive or simultaneous effects between traits. Those authors found evidence that SCS has a negative effect on milk yield (the infection effect, for which SCS is a standard indirect indicator), with an increase of 1 unit of SCS decreasing milk yield by about $1.1 \mathrm{~kg} / \mathrm{d}$; however, they did not find any reciprocal effect of milk production on SCS (dilution effect). Similar results were obtained by $\mathrm{Wu}$ et al. (2007), who used a Bayesian approach, compared with the maximum likelihood method used by de los Campos et al. (2006).

The lactose level in milk decreases during mastitis not only because of lower biosynthesis, but also because membrane permeability increases, allowing lactose to leak from the milk into the blood (Shuster et al., 1991); consequently, the milk contents of some minerals increase. As shown in Figure 1c, we observed that an increase in SCC was accompanied by a nonlinear reduction in lactose content, with lactose values remaining relatively constant in milk samples with SCS $<2$ but decreasing almost linearly above this value. The association between a high SCC and a decreased lactose concentration is well documented (Kitchen, 1981; Auldist et al., 1995; Wickström et al., 2009), and it has been proposed that lactose could be used to monitor udder health (Pyörälä, 2003). However, most of the existing reports have used a 2-level evaluation (low vs. high) to examine the effect of SCC on milk yield and composition; far fewer studies have examined response curves across different classes of SCC. Bruckmaier et al. (2004) observed lower lactose concentrations (43.8 vs. $48.1 \mathrm{~g} / \mathrm{L})$ in infected quarters $(\operatorname{logSCC} / \mathrm{mL}>6)$ compared with healthy contralateral quarters $(\operatorname{logSCC} / \mathrm{mL}$ $<5.2$ ), which was consistent with the previous findings of other authors (Fox et al., 1985; Harmon, 1994). As lactose content decreases, the concentrations of certain minerals (sodium and chloride) increase to maintain the osmotic equilibrium (Batavani et al., 2007). Moreover, lower values of casein might be observed in high SCC milk because of plasmin- and somatic-cell-proteasemediated activity against caseins, especially $\alpha_{\mathrm{S1}^{-}}$and $\beta$-casein (Urech et al., 1999). The changes in the ionic environment and the degradation of casein due to a higher enzymatic activity (Verdi et al., 1987; Franceschi et al., 2003) are responsible for the increase in milk $\mathrm{pH}$ observed during mastitis. This increase seems to follow a nonlinear quadratic trend (Figure 1e), with constant LSM values found for the first 4 classes of SCS, followed by moderate increases in classes 5,6 , and 7. Batavani et al. (2007) compared milk samples collected from healthy quarters and quarters with subclinical mastitis (defined as a leukocyte count $>500,000$ cells $/ \mathrm{mL}$ ) and found that the $\mathrm{pH}$ of mastitic milk was significantly higher than that of healthy milk (6.69 vs.

Table 3. Results from ANOVA ( $F$-value and significance) for traditional milk coagulation properties (MCP) and curd firming traits

\begin{tabular}{|c|c|c|c|c|c|c|c|c|c|}
\hline Trait $^{1}$ & DIM & Parity & Pendulum $^{2}$ & $\mathrm{SCS}^{3}$ & \multicolumn{3}{|c|}{ SCS Contrast } & Herd-date, ${ }^{4} \%$ & $\mathrm{RMSE}^{5}$ \\
\hline $\mathrm{RCT}, \min$ & $25.7^{* * *}$ & $2.9^{*}$ & 1.0 & $6.7^{* * *}$ & $15.5^{* * *}$ & $12.1^{* * *}$ & 1.3 & 14.6 & 4.95 \\
\hline $\mathrm{k}_{20}, \min$ & $4.6^{* * *}$ & 0.4 & $2.3^{* *}$ & 1.0 & 1.0 & 1.6 & 0.0 & 4.3 & 3.51 \\
\hline $\mathrm{a}_{30}, \mathrm{~mm}$ & $9.0^{* * *}$ & 2.0 & $2.4^{* *}$ & $2.6^{*}$ & $5.1^{*}$ & $4.6^{*}$ & 0.3 & 6.4 & 10.28 \\
\hline \multicolumn{10}{|l|}{ Curd firming } \\
\hline $\mathrm{k}_{\mathrm{CF}}, \% \times \min ^{-1}$ & $15.9^{* * *}$ & $3.3^{*}$ & $2.9^{* * *}$ & $2.3^{*}$ & $4.0^{*}$ & 1.2 & 0.1 & 13.8 & 5.00 \\
\hline $\mathrm{k}_{\mathrm{SR}}, \% \times \min ^{-1}$ & $2.4^{*}$ & $5.0^{* * *}$ & $18.4^{* * *}$ & 2.0 & 3.1 & 2.6 & 1.8 & 15.6 & 0.47 \\
\hline $\mathrm{CF}_{\max }, \mathrm{mm}$ & $20.1^{* * *}$ & $4.7^{* * *}$ & $5.1^{* * *}$ & $2.7^{*}$ & $9.7^{* *}$ & 2.6 & 0.8 & 21.9 & 6.02 \\
\hline $\mathrm{t}_{\max }, \min$ & $14.7^{* * *}$ & $5.2^{* * *}$ & $4.3^{* * *}$ & $3.0^{* *}$ & $7.3^{* *}$ & $5.7^{*}$ & 0.3 & 15.0 & 10.49 \\
\hline
\end{tabular}

${ }^{1} \mathrm{RCT}=$ rennet coagulation time; $\mathrm{k}_{20}=$ curd firming rate as time (min) to a curd firmness of $20 \mathrm{~mm}$; $\mathrm{a}_{30}=$ curd firmness after $30 \mathrm{~min}$ from rennet addition; $\mathrm{RCT}_{\mathrm{eq}}=$ rennet coagulation time estimated using the equation; $\mathrm{CF}_{\mathrm{P}}=$ potential asymptotic curd firmness at infinite time; $\mathrm{k}_{\mathrm{CF}}$ $=$ curd firming instant rate constant; $\mathrm{k}_{\mathrm{SR}}=$ syneresis instant rate constant; $\mathrm{CF}_{\max }=$ maximum curd firmness achieved within 45 min; $\mathrm{t}_{\max }=$ time at achievement of $\mathrm{CF}_{\max }$.

${ }^{2}$ Pendulum $=$ measuring unit of the coagulation meter.

${ }^{3} \mathrm{SCS}=\log _{2}(\mathrm{SCC} / 100,000)+3$.

${ }^{4}$ Herd-date effect expressed as proportion of variance explained by herd-test date calculated by dividing the corresponding variance component by the total variance.

${ }^{5} \mathrm{RMSE}=$ root mean square error.

${ }^{*} P<0.05 ;{ }^{* *} P<0.01 ; * * * P<0.001$. 
[a]

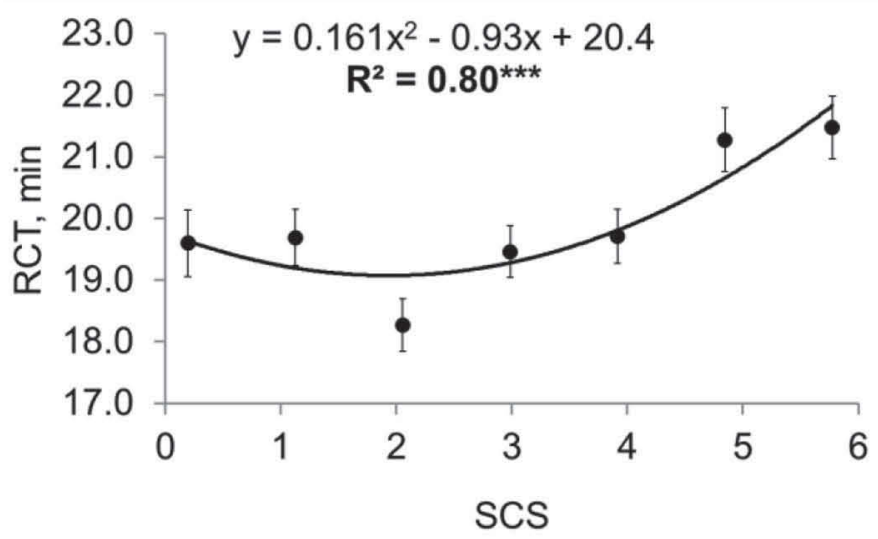

[c]

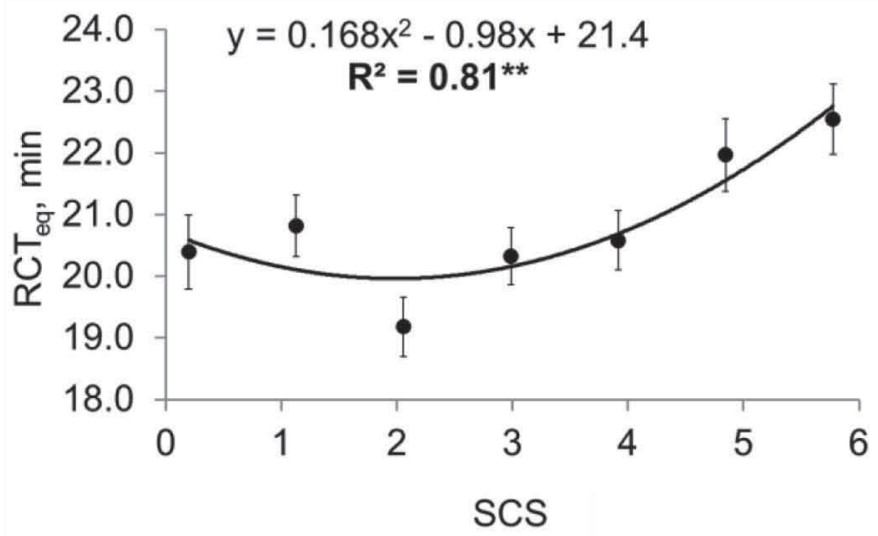

[e]

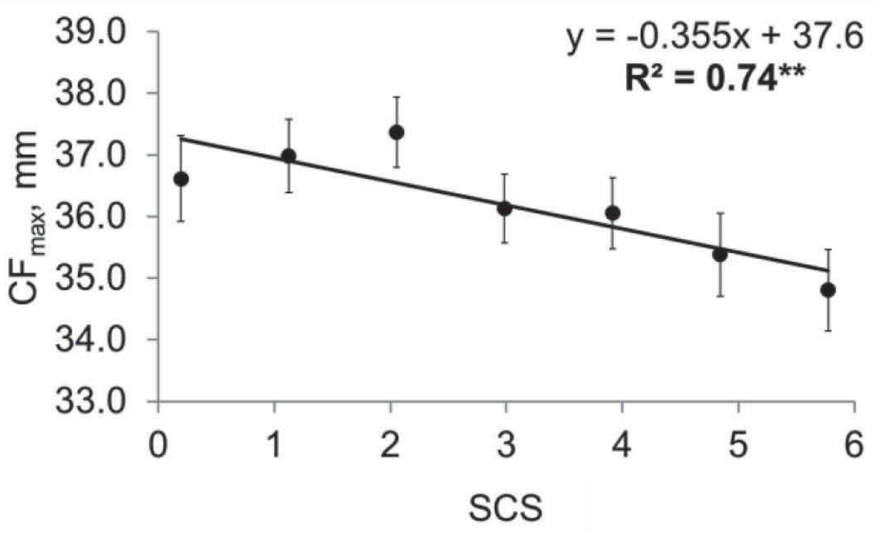

[b]

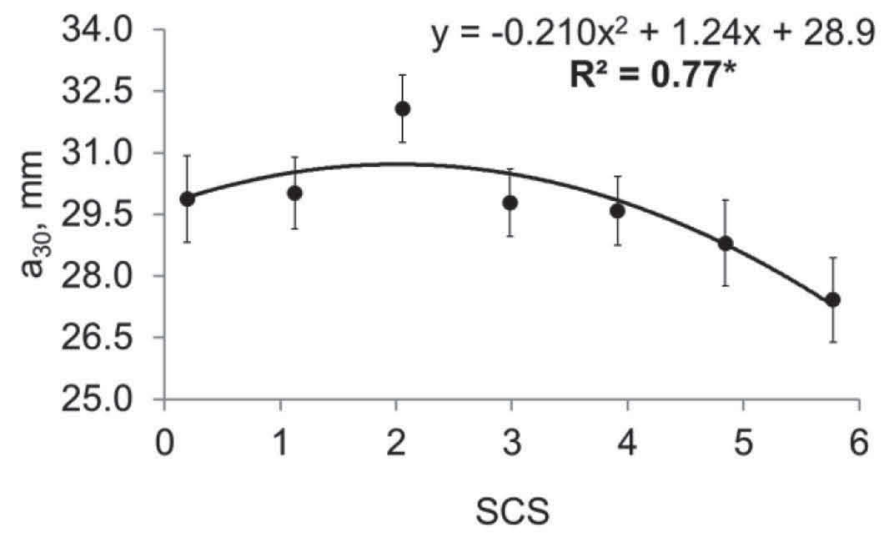

[d]

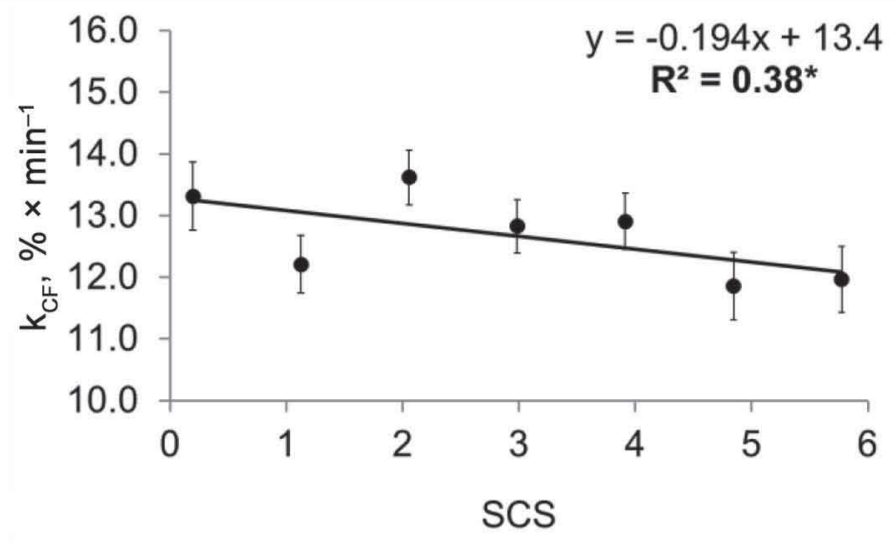

[f]

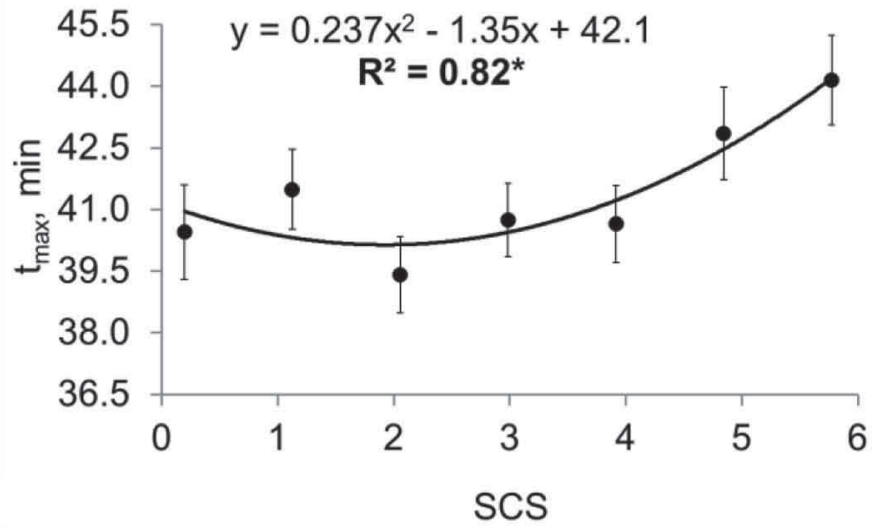

Figure 2. Least squares means of traditional milk coagulation properties (MCP) and curd firming traits across SCS. Results of the polynomial contrasts are reported: the response curve of the data across classes of SCS (linear or quadratic), the coefficient of determination ( $\mathrm{R}^{2}$ ) of the regression and the $P$-value of the polynomial contrasts. ${ }^{*} P<0.05 ;{ }^{* *} P<0.01 ;{ }^{*} * *<0.001$. RCT $=$ rennet coagulation time; $\mathrm{a}_{30}=$ curd firmness after $30 \mathrm{~min}$ from rennet addition; $\mathrm{RCT}_{\mathrm{eq}}=$ rennet coagulation time estimated using the equation; $\mathrm{k}_{\mathrm{CF}}=$ curd firming instant rate constant; $\mathrm{CF}_{\max }=$ maximum curd firmness achieved within $45 \mathrm{~min} ; \mathrm{t}_{\max }=$ time of achievement of $\mathrm{CF}_{\max }$. Error bars correspond to SE of LSM. 
6.59 , respectively; $P<0.01$ ). Vianna et al. (2008) investigated the effect of low $(<200,000$ cells $/ \mathrm{mL})$ and high $(>700,000$ cells $/ \mathrm{mL}$ ) SCC on raw milk composition and observed higher $\mathrm{pH}$ (6.85 vs. 6.76) and lower lactose values (4.53 vs. $4.69 \%)$ in high SCC milk. The effect of mastitis on the total protein content is controversial (Le Maréchal et al., 2011), but drastic changes clearly occur in the protein profile (Urech et al., 1999). The proteolysis of casein and the decreased synthesis of the major whey proteins, $\beta-\mathrm{LG}$ and $\alpha-\mathrm{LA}$, are balanced by increases in the contents of BSA and immunoglobulin via leakage through the blood-milk barrier (Haenlein et al., 1973). Thus, the total protein content in milk may not be significantly influenced by high SCC (Munro et al., 1984). In the present study, the casein and protein contents were not affected by the SCS class, but the casein:protein ratio was affected (Table 2). In fact, the casein number was influenced by high SCC, and showed a nonlinear quadratic pattern similar to that observed for lactose content (Figure 1b). Geary et al. (2013) performed a meta-analysis on the data available in the literature and estimated the relationships between SCC and milk composition traits. A total of 32 published articles, mostly based on 2- or 3-class (low, intermediate, and high SCC) evaluations, were included in the analysis. Significant $(P<0.01)$ negative linear relationships were found between SCS and lactose content, and between SCS and casein number. Quadratic and cubic effects were also tested in the random regression models but they were not significant. Coulon et al. (1998) reported that the decrease in casein number became significant when SCC >200,000 cells/mL; this value corresponds to our SCS class 4, which is the class in which we observed the casein number begin to decrease as SCS increased (Figure 1b). Notably, an SCC $>200,000$ cells $/ \mathrm{mL}$ is considered the threshold value for detecting subclinical mastitis at the individual cow level (Guidry, 1985).

\section{SCS Affects Variation in Milk Coagulation and Curd Firming Pattern}

Although cheese production is a major use of milk, relatively few studies have examined the effect of SCC on the cheese-making process or the properties of the produced cheese (Le Maréchal et al., 2011). Nonetheless, a high milk SCC is generally recognized to affect not only milk composition, but also the technological traits related to clotting ability and cheese processing (Barbano et al., 1991; Auldist and Hubble, 1998). As variation in milk $\mathrm{pH}$ could strongly affect both traditional MCP and the $\mathrm{CF}_{\mathrm{t}}$ parameters (Stocco et al., 2015), the main effect of SCS on these traits could reflect increases in $\mathrm{pH}$ caused by subclinical mastitis. Higher $\mathrm{pH}$, in association with elevated SCC, negatively affects the cheese-making ability of milk by decreasing the activities of clotting-related enzymes (Swaisgood, 1982). Moreover, alterations in casein may also affect milk coagulation, as proteose-peptones released during the degradation of casein seem to have negative effects on clotting time, curd firmness, and curd formation (Le Maréchal et al., 2011). In the present study, the increased alkalinity and lower casein numbers of milk samples characterized by SCS $>3$ were responsible for a prolonged coagulation time (RCT, Figure $2 \mathrm{a} ; \mathrm{RCT}_{\text {eq }}$, Figure $2 \mathrm{c}$ ) and a weaker coagulum $\left(\mathrm{a}_{30}\right.$, Figure $\left.2 \mathrm{~b}\right)$ with

Table 4. Results from ANOVA ( $F$-value and significance) for cheese yield $(\% \mathrm{CY})$ and milk nutrient recovery in curd (REC)

\begin{tabular}{|c|c|c|c|c|c|c|c|c|c|}
\hline Trait $^{1}$ & DIM & Parity & Vat/WB ${ }^{2}$ & $\mathrm{SCS}^{3}$ & \multicolumn{3}{|c|}{ SCS contrast } & Herd-date, ${ }^{4} \%$ & $\mathrm{RMSE}^{5}$ \\
\hline \multicolumn{10}{|c|}{ Cheese yield (\%CY) } \\
\hline$\% \mathrm{CY}_{\text {SOLIDS }}$ & $39.8^{* * *}$ & 1.2 & 1.6 & 1.1 & 0.2 & 3.5 & 0.1 & 19.7 & 0.76 \\
\hline$\% \mathrm{CY}_{\text {WATER }}$ & $37.0^{* * *}$ & $5.6^{* * *}$ & 1.3 & $4.2^{* * *}$ & $16.5^{* * *}$ & $5.0^{*}$ & 0.6 & 41.5 & 0.90 \\
\hline \multicolumn{10}{|c|}{ Nutrient recovery (REC) } \\
\hline $\mathrm{REC}_{\text {SOLIDS }}, \%$ & $33.8^{* * *}$ & 0.5 & 1.7 & 1.3 & 1.7 & 2.2 & 0.8 & 20.1 & 2.92 \\
\hline REC $_{\text {ENERGY }}, \%$ & $9.5^{* * *}$ & 0.2 & 1.7 & 1.5 & 0.9 & $5.5^{*}$ & 0.8 & 20.2 & 2.89 \\
\hline \multirow{3}{*}{\multicolumn{10}{|c|}{$\begin{array}{l}{ }_{1} \% \mathrm{CY}_{\mathrm{CURD}}=\text { fresh cheese yield; } \% \mathrm{CY}_{\text {SOLIDS }}=\text { total solids cheese yield; } \% \mathrm{CY}_{\mathrm{WATER}}=\text { water entrapped in the curd; } \mathrm{REC} \mathrm{CROTEIN}_{\mathrm{PR}}, \%=\text { protein } \\
\text { retention; } \mathrm{REC}_{\mathrm{FAT}}, \%=\text { fat retention; } \mathrm{REC}_{\mathrm{SOLIDS}}, \%=\text { total solids retention; } \mathrm{REC}_{\mathrm{ENERGY}} \%=\text { energy retention. } \\
{ }^{2} \mathrm{WB}=\text { water bath. }\end{array}$}} \\
\hline & & & & & & & & & \\
\hline & & & & & & & & & \\
\hline \multicolumn{10}{|c|}{${ }^{3} \mathrm{SCS}=\log _{2}(\mathrm{SCC} / 100,000)+3$} \\
\hline
\end{tabular}


[a]

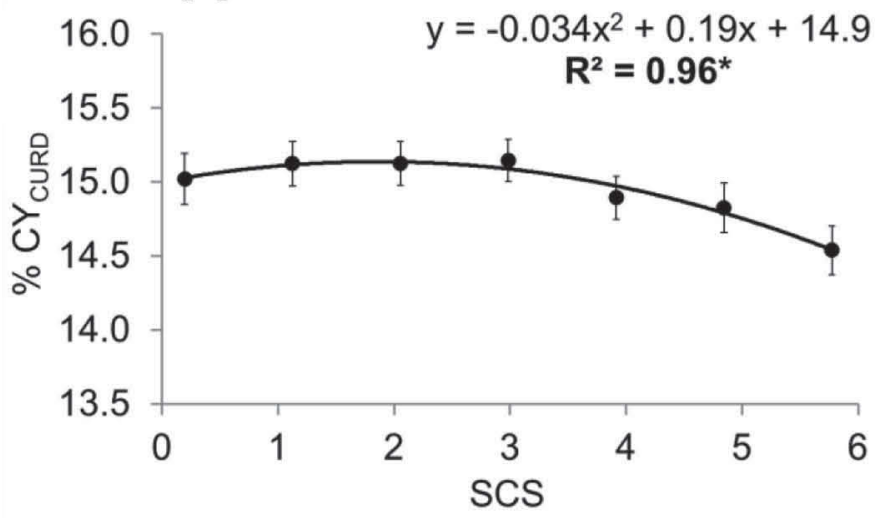

[c]

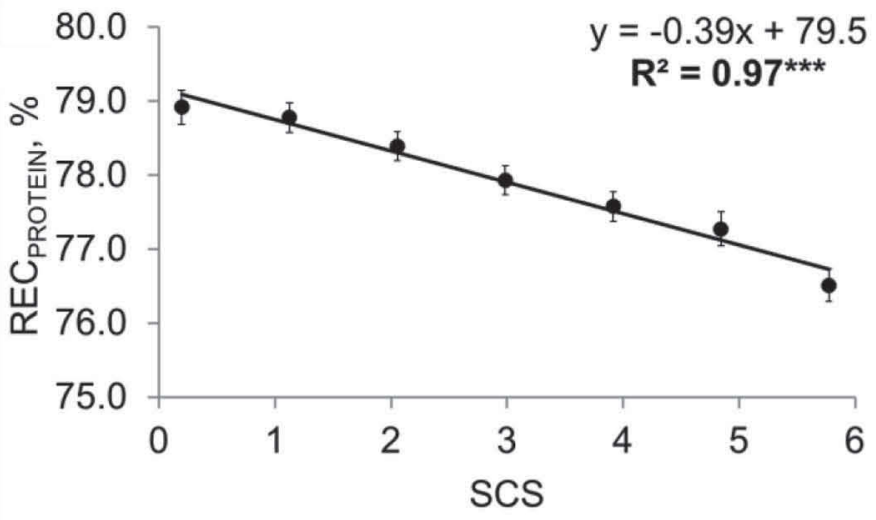

[e]

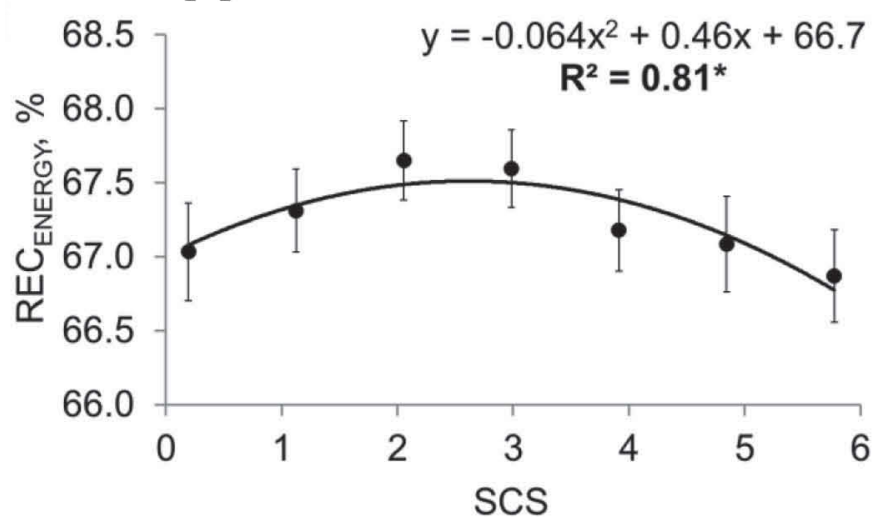

[b]

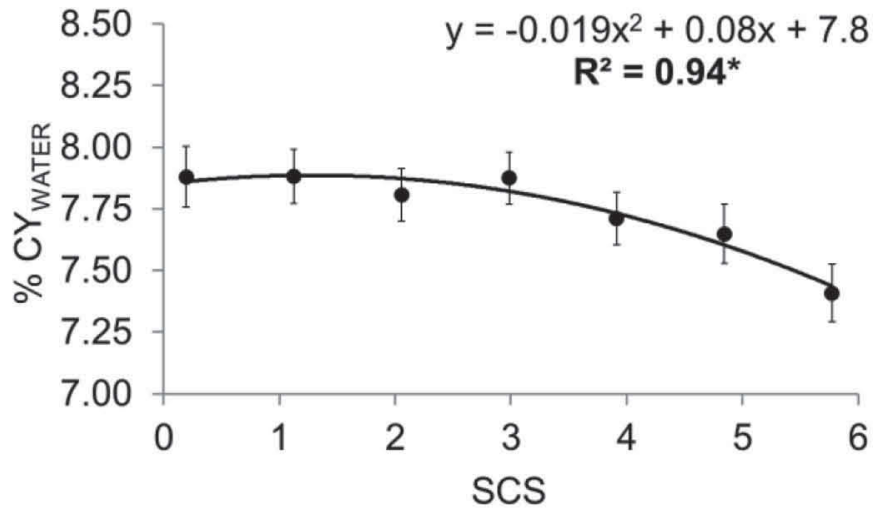

[d]

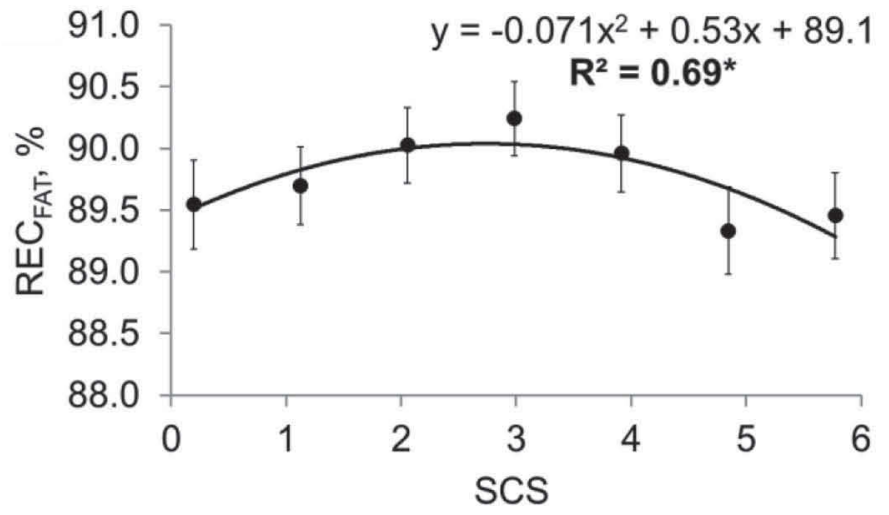

Figure 3. Least squares means of cheese yield traits (\%CY) and milk nutrient recovery in curd (REC) across SCS. Results of the polynomial contrasts have been reported: the response curve of the data across classes of SCS (linear or quadratic), the coefficient of determination ( $\left.{ }^{2}\right)$ of the regression and the $P$-value of the polynomial contrasts. ${ }^{*} P<0.05$; $* * * P<0.001$. Error bars correspond to SE of LSM.

reduced syneresis; moreover, a nonlinear quadratic relationship was observed between MCP and SCS. Associations between elevated SCC and reduced MCP (e.g., longer rennet clotting time and lower curd firmness) have been described in the literature (Munro et al., 1984; Rogers and Mitchell, 1994; Klei et al., 1998). Ng-Kwai-Hang et al. (1989) reported that gelation was delayed (+5 min) as milk SCC increased from 100,000 to 600,000 cells $/ \mathrm{mL}$. Pellegrini et al. (1994) found that the coagulation time of ewe milk increased $\sim 5 \mathrm{~min}$ between class 1 ( SCC $<100,000$ cells $/ \mathrm{mL}$ ) and class 4 (SCC >500,000 cells/mL). In a recent paper, Vásquez et al. (2014) reported a positive (unfavorable) linear relationship between $\mathrm{SCC}$ and $\mathrm{RCT}$, with the latter 
increasing by $0.9 \mathrm{~min}(54 \mathrm{~s})$ for each increase in SCC of 100,000 cells $/ \mathrm{mL}$. It should be noted that the effect of clinical or subclinical mastitis is not fully represented in the traditional MCP because these tests are often limited to $30 \mathrm{~min}$. Certain relevant factors (e.g., an increased SCC) can delay gelation time, thereby increasing the incidence of samples that fail to coagulate within the test duration [called noncoagulating ( $\mathrm{NC}$ ) milk, as reviewed by Bittante et al. (2012)].

The newer strategy of prolonging observation time and modeling all available information allows the estimation of more informative parameters. In the present study, the test was prolonged to $90 \mathrm{~min}$, which allowed almost all of the samples to coagulate, as previously described (Cipolat-Gotet et al., 2012). Moreover, the modeling of all 360 data points available for each milk sample increased the repeatability of the trait measures. The traditional (RCT; Figure 2a) and modeled $\left(\mathrm{RCT}_{\text {eq }}\right.$; Figure 2c) gelation times both showed clear nonlinear patterns, with the best results yielded by milk samples of the SCS class centered on the value of 2 (corresponding to a SCC of 50,000 cells $/ \mathrm{mL}$ ). The high-SCS-related delay in gelation time was consistent with previous reports (Barbano et al., 1991; Auldist and Hubble, 1998). However, we also observed that gelation was delayed in milk samples with very low $\operatorname{SCS}(<2)$.

It is difficult to directly compare the present work with prior studies that used linear covariates, assessed only 2 or 3 classes of SCC, or (when more classes were examined) tested distributions from milk with higher SCC than examined in the present study. For example, Politis and Ng-Kwai-Hang (1988) reported that RCT values remained relatively constant for classes with 100,000 to 500,000 somatic cells $/ \mathrm{mL}$, and thereafter increased as the SCC increased to over 1,000,000 cells/ $\mathrm{mL}$. However, the authors did not report any SCC class below 100,000 cells/mL. Regarding the variation of traditional RCT with increasing SCS, our results are consistent with those of Toffanin et al. (2012), although they used bulk milk samples and did not test the data for nonlinearity.

The published reports regarding the effect of SCC on the other traditional MCP are more variable. This is also due to the biases induced on the $\mathrm{a}_{30}$ trait by NC samples, which has often been excluded from data analyses or assumed to have a 0 value, or on the $k_{20}$ trait, which presents a much higher (compared with noncoagulating samples) frequency of samples not reaching $20 \mathrm{~mm}$ of curd firmness within the usual 30min time limit (Bittante et al., 2012). Because of this problem, many studies do not consider $\mathrm{k}_{20}$. Here, prolonging the test duration allowed us to record $\mathrm{a}_{30}$ and $\mathrm{k}_{20}$ values for almost all of the analyzed samples. Our results showed that SCS did not have a significant effect on $\mathrm{k}_{20}$, whereas its effect on $\mathrm{a}_{30}$ was characterized by a pattern (Figure 2b) opposite than that observed for RCT (Figure 2a). This confirms the strong correlation of these 2 traits and emphasizes that little information is gained from the latter when the former is known.

Considering the new model-based curd firming traits, SCS did not affect potential curd firmness $\left(\mathrm{CF}_{\mathrm{P}}\right)$ or the syneresis rate constant of curd $\left(\mathrm{k}_{\mathrm{SR}}\right.$; the velocity at which whey is expelled from the curd). It did, however, exert an almost linear negative effect on the curd firming instant rate constant $\left(\mathrm{k}_{\mathrm{CF}}\right.$, Figure $\left.2 \mathrm{~d}\right)$, which was reflected by the similar negative effect on maximum curd firmness $\left(\mathrm{CF}_{\max }\right.$, Figure 2e) and the curvilinear effect on the time at which $\mathrm{CF}_{\max }$ was achieved $\left(t_{\max }\right.$, Figure 2f).

\section{SCS Affects Variation of Cheese Yield and Milk Nutrient Recovery in Curd or Loss in Whey}

Milk coagulation properties are important for 2 main reasons: (1) they are technologically valuable for optimizing the cheese-making process and predicting possible abnormalities during the process and in the final product; and (2) they may be used to indirectly predict cheese yield, especially with respect to fines losses in whey and the moisture retained in the curd. This second aspect is important because the MCP are relatively easy to measure in multiple samples at the laboratory level, whereas direct measurements of the \%CY and REC traits are expensive and time-consuming.

The experimental results about the possibility of indirect prediction of cheese yield are controversial. Some authors failed to find significant differences in cheese yield between milk with good versus poor clotting abilities (Ikonen et al., 1999; Bonfatti et al., 2014), whereas others found that better MCP were associated with higher cheese yield and increased recovery of milk protein and fat in the curd (Aleandri et al., 1989; Malacarne et al., 2006). Recent work performed by Cecchinato and Bittante (2016) on a large data set revealed weak relationships between traditional MCP and the $\% \mathrm{CY}$ and REC traits but stronger correlations with the parameters depicting the latter portion of the $\mathrm{CF}_{\mathrm{t}}$ curve (especially $\mathrm{CF}_{\mathrm{P}}$ and $\mathrm{k}_{\mathrm{SR}}$ ).

In studies involving a small number of experimental cheese-making sessions, some authors reported that the cheese yield decreased as the SCC increased (Ali et al., 1980; Munro et al., 1984; Barbano et al., 1991). In particular, high SCC was shown to reduce the yields of cottage (Vianna et al., 2008), Parmigiano Reggiano (Summer et al., 2015), and Cheddar (Grandison and Ford, 1986; Auldist et al., 1996; Marino et al., 2005) cheeses, whereas it seemed not to affect Prato cheese (Mazal et al., 2007; Vianna et al., 2008) or mozzarella 
(Andreatta et al., 2007). However, most of these studies used bulk milk, enrolled a limited number of samples to compare low versus high SCC, and did not consider the patterns across different classes of SCS.

In the present study, we observed a longer coagulation time and weaker curd firmness at the time of cutting; this likely reflected the impaired acidification of mastitic milk, which leads to a greater loss of nutrients in the whey (Figure 3c-e). Moreover, the mean value of $\mathrm{REC}_{\text {Protein }}(78.1 \%$, Table 1) was, as expected, close to the mean value of the casein number $(77.1 \%$, Table 1$)$, and the 2 traits showed similar, almost linear, patterns with increasing SCS. The total variation induced by

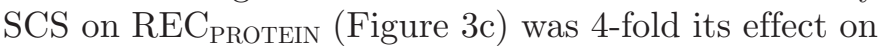
casein number (Figure 1c), indicating that the negative effect of somatic cells in milk is not limited to modification of the casein:total protein ratio but also involves a loss of casein in the whey. In fact, although the nitrogen content remains constant, less casein is incorporated in the reticulum of the curd during cheese-making (Ali et al., 1980), decreasing the curd tension at the time of the cutting (Yun et al., 1982), reducing cheese yield, and triggering a greater nutrient loss (Bynum and Olson, 1982). Positive relationships between SCC and protein losses into the whey were also reported by Politis and Ng-Kwai-Hang (1988) and Barbano et al. (1991).
Unlike the recovery of protein, the recoveries of milk fat $\left(\mathrm{REC}_{\mathrm{FAT}}\right.$, Figure $\left.3 \mathrm{~d}\right)$ and (consequently) milk energy (REC $\mathrm{R}_{\text {ENERGY }}$, Figure 3e) showed evident nonlinear quadratic trends, with the highest recoveries yielded by the milk samples with intermediate SCS and slightly lower values for milk samples with both smaller and greater SCS. Summer et al. (2015) reported that high SCC has a negative effect on fat recovery in cheese due to increased lipolysis. In contrast, no change in the loss of fat into the whey was reported by Politis and Ng-Kwai-Hang (1988), Mazal et al. (2007), or Vianna et al. (2008).

Increasing SCS was associated with a decrease in the water retained in the curd $\left(\% \mathrm{CY}_{\text {WATER }}\right.$, Figure $\left.3 \mathrm{~b}\right)$, especially for SCS $<3$, yielding a parallel decrease of $\% \mathrm{CY}_{\text {CURD }}$ (Figure 3a). Interestingly, both high and low SCC appeared to affect some of the technological traits of milk. For example, milk belonging to SCS classes 1 and 2 (corresponding to $\mathrm{SCC}<38,000$ cells/mL) was characterized by slower coagulation (Figure 2a), lower curd firmness (Figure 2b), and lower recoveries of fat (Figure 3d) and energy (Figure 3e) in the curd compared with milk of the intermediate classes of SCS. When we represented the equations using the LSM of the new curd firming traits (Figure 4), we detected differences in curd firmness between SCS classes 1, 3, and

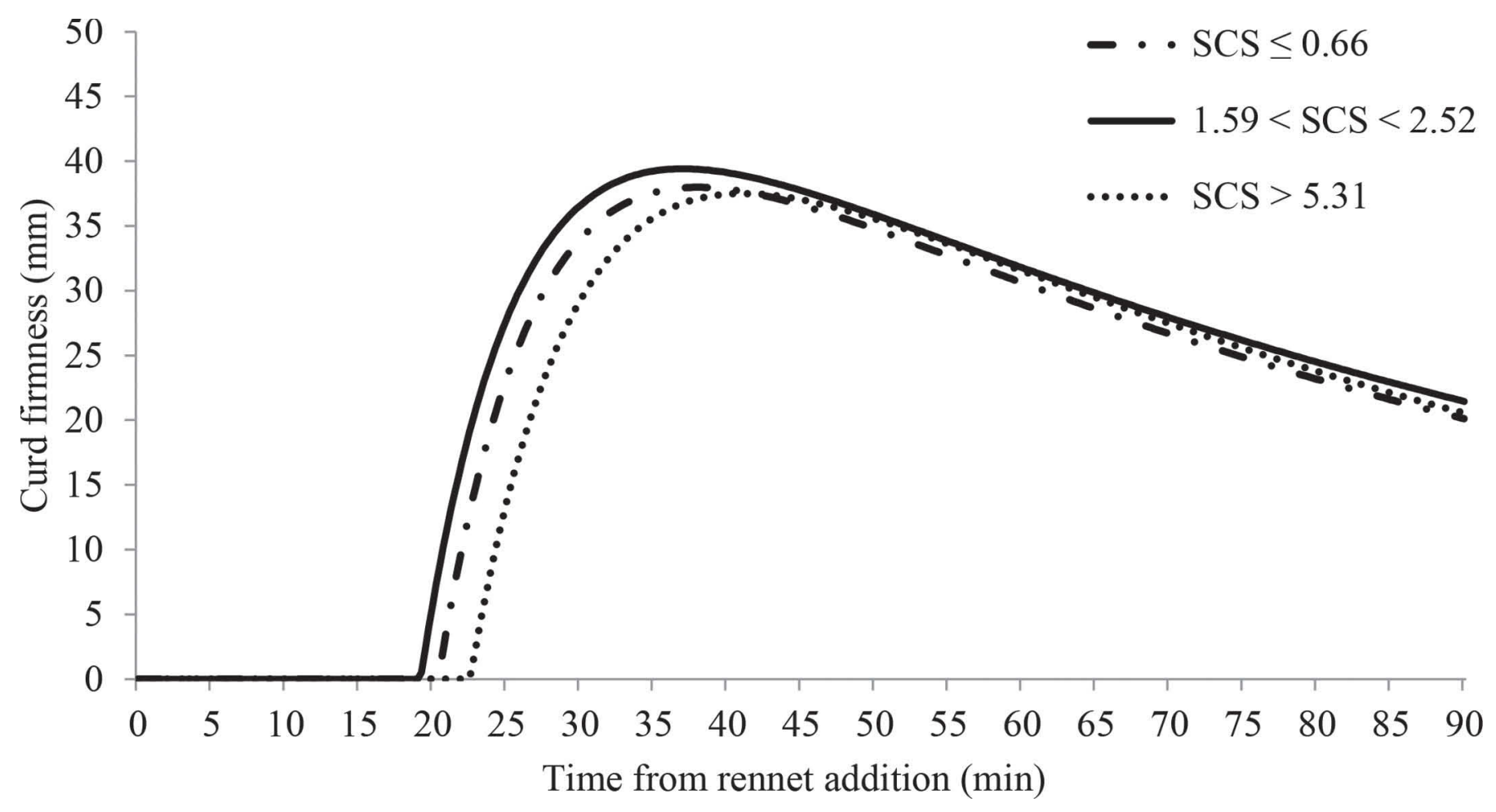

Figure 4. Curd firmness modeling for classes $1(\leq 0.66), 3(1.59-2.52)$, and 7 (>5.31) of SCS. 
7 , with the best results obtained from milk belonging to the third class. Low SCC $(<200,000$ cells $/ \mathrm{mL})$ was previously reported as a possible risk factor for clinical mastitis (Suriyasathaporn et al., 2000) and might be associated with a reduced immune response to infections. The milk of healthy cows contains a resident leukocyte population that plays a key role in innate defense, and cows with very low milk SCC were reported to exhibit a less-efficient response to IMI (Wellnitz et al., 2010). Thus, we speculate that some of the cows belonging to SCS class 1 had deficits in their immune responses and were affected by an undetectable mastitic event that had slight effects on milk yield (Figure 1a), casein number (Figure 1b), and lactose content (Figure 1c). This could explain why these values were lower for class 1 than for classes 2 and 3. Moreover, the $\mathrm{pH}$ was slightly higher in class 1 milk compared with the intermediate classes, worsening the technological traits of this lowSCC milk.

\section{CONCLUSIONS}

The results of the present study confirmed the negative effect of high SCC (indicator of mammary gland inflammation) on milk yield, milk composition, milk coagulation properties, and cheese-related traits. This study offers new insights into the relationships between the aforementioned variables, and explores the response curve of data obtained from individual milk samples across different classes of SCS. Our results show nonlinear trends for some milk composition and technological traits with respect to SCS. This is the first report to test the relationships between SCS and new technological traits [i.e., curd firming traits, syneresis traits, individual cheese yield (\%CY) and curd nutrient recoveries (REC)]. As SCS increased, we observed a linear loss of milk production and several changes in milk composition. These variations decreased the quality and clotting ability of the milk, which showed slower coagulation and weaker curd firmness. This consequently decreased the cheese processing and cheese-making properties (as shown by reductions in the cheese yield and recoveries of nutrients in the curd). Further studies will be required to clarify the relationships between results obtained analyzing individual and bulk samples, and the nonlinear relationships between SCS and milk technological traits observed in this study should be considered in genetic analysis. New studies are needed to explore the negative effect of low SCC on milk technological traits, as milk of SCS classes 1 and 2 showed slower coagulation, lower curd firmness, and lower nutrient recoveries in the curd. Moreover, as mastitis may be caused by different pathogens that raise different immune responses, such variations should be consid- ered in future investigations of how mastitis affects milk quality and technological traits.

\section{ACKNOWLEDGMENTS}

This research was supported by the University of Padova (CPDA 114230/11). The authors acknowledge the Superbrown Consortium of Bolzano and Trento (Trento, Italy) for the support in sampling and recording activities.

\section{REFERENCES}

Aleandri, R., J. C. Schneider, and L. G. Buttazzoni. 1989. Evaluation of milk for cheese production based on milk characteristics and Formagraph measures. J. Dairy Sci. 72:1967-1975.

Ali, A. E., A. T. Andrews, and G. C. Cheeseman. 1980. Influence of elevated somatic cell count on casein distribution and cheesemaking. J. Dairy Res. 47:393-400.

Ali, A. K. A., and G. E. Shook. 1980. An optimum transformation for somatic cell concentration in milk. J. Dairy Sci. 63:487-490.

Andreatta, E., A. M. Fernandes, M. Veiga Dos Santos, C. Goncalves De Lima, C. Mussarelli, M. C. Marques, and C. Auguste Fernandes De Oliveira. 2007. Effects of milk somatic cell count on physical and chemical characteristics of mozzarella cheese. Aust. J. Dairy Technol. 62:166-170.

Annibaldi, S., F. Ferri, and R. Morra. 1977. Nuovi orientamenti nella valutazione tecnica del latte: Tipizzazione lattodinamografica. Sci. Tecn. Latt. Cas. 28:115-126.

Auldist, M. J., S. Coats, G. L. Rogers, and G. H. McDowell. 1995. Changes in the composition of milk from normal and mastitic dairy cows during lactational cycle. Aust. J. Exp. Agric. 35:427-436.

Auldist, M. J., S. Coats, B. J. Sutherland, J. J. Mayes, G. H. McDowell, and G. L. Rogers. 1996. Effects of somatic cell count and stage of lactation on raw milk composition and the yield and quality of Cheddar cheese. J. Dairy Res. 63:269-280.

Auldist, M. J., and I. B. Hubble. 1998. Effects of mastitis on raw milk and dairy products. Aust. J. Dairy Technol. 53:28-36.

Banks, J. M. 2007. Cheese yield. Pages 100-114 in Cheese Problems Solved. P. L. H. McSweeney, ed. Woodhead Publishing Ltd., Cambridge, UK.

Barbano, D. M., R. R. Rasmussen, and J. M. Lynch. 1991. Influence of milk somatic cell count and milk age on cheese yield. J. Dairy Sci. 74:369-388.

Barłowska, J., Z. Litwińczuk, A. Wolanciuk, and A. Brodziak. 2009 Relationship of somatic cell count to daily yield and technological usefulness of milk from different breeds of cows. Pol. J. Vet. Sci. $12: 75-79$.

Batavani, R. A., S. Asri, and H. Naebzade. 2007. The effect of subclinical mastitis on milk composition in dairy cows. Iranian J. Vet. Res. 8:205-211.

Bittante, G. 2011. Modeling rennet coagulation time and curd firmness of milk. J. Dairy Sci. 94:5821-5832.

Bittante, G., C. Cipolat-Gotet, F. Malchiodi, E. Sturaro, F. Tagliapietra, S. Schiavon, and A. Cecchinato. 2015. Effect of dairy farming system, herd, season, parity, and days in milk on modeling of the coagulation, curd firming, and syneresis of bovine milk. J. Dairy Sci. 98:2759-2774.

Bittante, G., B. Contiero, and A. Cecchinato. 2013. Prolonged observation and modelling of milk coagulation, curd firming, and syneresis. Int. Dairy J. 29:115-123.

Bittante, G., M. Penasa, and A. Cecchinato. 2012. Invited review: Genetics and modeling of milk coagulation properties. J. Dairy Sci. 95:6843-6870.

Bonfatti, V., M. Tuzzato, G. Chiarot, and P. Carnier. 2014. Variation in milk coagulation properties does not affect cheese yield and composition of model cheese. Int. Dairy J. 39:139-145. 
Bruckmaier, R. M., C. E. Ontsouka, and W. Blum. 2004. Fractionized milk composition in dairy cows with subclinical mastitis. Vet. Med. Czech. 49:283-290.

Bynum, D. G., and N. F. Olson. 1982. Influence of curd firmness at cutting on the Cheddar cheese yield and recovery of milk constituents. J. Dairy Sci. 65:2281-2290.

Cecchinato, A., and G. Bittante. 2016. Genetic, herd/date and environmental relationships of different measures of individual cheese yield and curd nutrients recovery/whey loss and with coagulation properties of bovine milk. J. Dairy Sci. 99:1975-1989.

Cecchinato, A., C. Cipolat-Gotet, J. Casellas, M. Penasa, A. Rossoni, and G. Bittante. 2013. Genetic analysis of rennet coagulation time, curd-firming rate, and curd firmness assessed on an extended testing period using mechanical and near-infrared instruments. J. Dairy Sci. 96:50-62.

Cipolat-Gotet, C., A. Cecchinato, M. De Marchi, and G. Bittante. 2013. Factors affecting variation of different measures of cheese yield and milk nutrient recovery from an individual model cheesemanufacturing process. J. Dairy Sci. 96:7952-7965.

Cipolat-Gotet, C. A. Cecchinato, M. De Marchi, M. Penasa, and G. Bittante. 2012. Comparison between mechanical and near-infrared optical methods for assessing milk coagulation properties. J. Dairy Sci. 95:6806-6819.

Coulon, J. B., C. Hurtaud, B. Remond, and R. Verite. 1998. Factors contributing to variation in the proportion of casein in cows' milk true protein: A review of recent INRA experiments. J. Dairy Res. 65:375-387.

de los Campos, G., D. Gianola, and B. Heringstad. 2006. A structural equation model for describing relationships between somatic cell count and milk yield in first-lactation dairy cows. J. Dairy Sci. 89:4445-4455.

Fox, L. K., G. E. Shook, and L. H. Schultz. 1985. Factors related to milk loss in quarters with low somatic cell counts. J. Dairy Sci. 68:2100-2107.

Franceschi, P., P. Formaggioni, M. Malacarne, A. Summer, S. Fieni, and P. Mariani. 2003. Variations of nitrogen fractions, proteolysis and rennet-coagulation properties of milks with different somatic cell values. Sci. Tecn. Latt. Cas. 54:301-310.

Geary, U., N. Lopez-Villalobos, B. O'Brien, D. J. Garrick, and L. Shalloo. 2013. Meta-analysis to investigate relationships between somatic cell count and raw milk composition, Cheddar cheese processing characteristics and cheese composition. Ir. J. Agric. Food Res. 52:119-133.

Grandison, A. S., and G. D. Ford. 1986. Effects of variations in somatic cell count on the rennet coagulation properties of milk and on the yields, composition and quality of cheddar cheese. J. Dairy Res. 53:645-655.

Guidry, A. J. 1985. Mastitis and the immune system of the mammary gland. Page 249 in Lactation. B. L. Larson, ed. Iowa State Univ. Press, Ames.

Haenlein, G. F., L. H. Schultz, and J. P. Zikakis. 1973. Comparison of proteins in milk with varying leukocyte contents. J. Dairy Sci. $56: 1017-1024$

Harmon, R. J. 1994. Physiology of mastitis and factors affecting somatic cell counts. J. Dairy Sci. 77:2103-2112.

Ikonen, T., O. Ruottinen, E. L. Syväoja, K. Saarinen, E. Pahkala, and M. Ojala. 1999. Effect of milk coagulation properties of herd bulk milk on yield and composition of Emmental cheese. Agric. Food Sci. Finl. 8:411-422.

Ingvartsen, K. L., R. J. Dewhurst, and N. C. Friggens. 2003. On the relationship between lactational performance and health: is it yield or metabolic imbalance that causes diseases in dairy cattle? A position paper. Livest. Prod. Sci. 83:277-308.

International Dairy Federation. 2013. The world dairy situation. Bulletin 470/2013. International Dairy Federation, Brussels, Belgium.

ISO. 2002. Dried milk, dried ice-mixes and processed cheese-Determination of lactose content-Part 1: Enzymatic method utilizing the galactose moiety of the lactose (ISO 5765-1|IDF 79-1). International Organization for Standardization, Geneva, Switzerland.
ISO. 2004a. Milk-Determination of casein-nitrogen content-Part 1: Indirect method (ISO 17997-1:2004|IDF 29). International Organization for Standardization, Geneva, Switzerland.

ISO. 2004b. Milk-Determination of urea content-Enzymatic method using difference in pH (ISO 14637:2004|IDF 195). International Organization for Standardization, Geneva, Switzerland.

ISO. 2010a. Milk, cream and evaporated milk-Determination of total solids content (ISO 6731:2010|IDF 21). International Organization for Standardization, Geneva, Switzerland.

ISO. 2010b. Milk - Determination of fat content-Gravimetric method (ISO 1211:2010|IDF 1). International Organization for Standardization, Geneva, Switzerland.

ISO. 2014. Milk and milk products-Determination of nitrogen content-Part 1: Kjeldahl principle and crude protein calculation (ISO 8968-1:2014|IDF 20-1). International Organization for Standardization, Geneva, Switzerland.

Kitchen, B. J. 1981. Review of the progress of dairy science: Bovine mastitis - Milk compositional changes and related diagnostic tests. J. Dairy Res. 48:167-188.

Klei, L., J. Yun, A. Sapru, J. Lynch, D. M. Barbano, P. Sears, and D. Galton. 1998. Effect of milk somatic cell count on cottage cheese and quality. J. Dairy Sci. 81:1205-1213.

Koldeweij, E., U. Emanuelson, and L. Janson. 1999. Relation of milk production loss to somatic cell count. Acta Vet. Scand. 40:47-56.

Le Maréchal, C., R. Thiéry, E. Vautor, and Y. Le Loir. 2011. Mastitis impact on technological properties of milk and quality of milk products-A review. Dairy Sci. Technol. 91:247-282.

Malacarne, M., A. Summer, E. Fossa, P. Formaggioni, P. Franceschi, M. Pecorari, and P. Mariani. 2006. Composition, coagulation properties and Parmigiano-Reggiano cheese yield of Italian Brown and Italian Friesian herd milks. J. Dairy Res. 73:171-177.

Marino, R., T. Considine, A. Sevi, P. L. H. McSweeney, and A. L. Kelly. 2005. Contribution of proteolytic activity associated with somatic cells in milk to cheese ripening. Int. Dairy J. 15:1026-1033.

Mazal, G., P. C. B. Vianna, M. V. Santos, and M. L. Gigante. 2007 Effect of somatic cell count on Prato cheese composition. J. Dairy Sci. 90:630-636.

McMahon, D. J., and R. J. Brown. 1982. Evaluation of Formagraph for comparing rennet solutions. J. Dairy Sci. 65:1639-1642.

Miglior, F., B. L. Muir, and B. J. Van Doormaal. 2005. Selection Indices in Holstein cattle of various countries. J. Dairy Sci. 88:12551263

Munro, G. L., P. A. Grieve, and B. J. Kitchen. 1984. Effects of mastitis on milk yield, milk composition, processing properties and yield and quality of milk products. Aust. J. Dairy Technol. 39:7-16.

Ng-Kwai-Hang, K. F., I. Politis, R. I. Cue, and A. S. Marziali. 1989. Correlations between coagulation properties of milk and cheese yielding capacity and cheese composition. Can. Inst. Food Sci. Technol. J. 22:291-294.

NRC. 2001. Nutrient Requirements of Dairy Cattle. 7th rev. ed. Natl. Acad. Sci., Washington, DC.

Oltenacu, P. A., and D. M. Broom. 2010. The impact of genetic selection for increased milk yield on the welfare of dairy cows. Anim. Welf. 19:39-49.

Pellegrini, O., M. R. Aurel, G. Lagriffoul, C. Marie-Etancelin, F. Remeuf, M. Rivemale, and F. Barillet. 1994. Relations entre les comptages de cellules somatiques, les caractéristiques physicochimiques et l'aptitude à la coagulation par la présure de laits individuels de brebis de race Lacaune. In Somatic Cells and Milk of Small Ruminants. International Symposium, Bella, Italy. EAAP Publication (Italy) eng no. 77.

Politis, I., and K. F. Ng-Kwai-Hang. 1988. Effects of somatic cell count and milk composition on cheese composition and cheese making efficiency. J. Dairy Sci. 71:1711-1719.

Pyörälä, S. 2003. Indicators of inflammation in the diagnosis of mastitis. Vet. Res. 34:565-578.

Rogers, S. A., and G. E. Mitchell. 1994. The relationship between somatic cell count, composition and manufacturing properties of bulk milk 6 . Cheddar cheese and skim milk yoghurt. Aust. J. Dairy Technol. 49:70-74. 
Schallibaum, M. 2001. Impact of SCC on the quality of fluid milk and cheese. Pages 38-46 in Proc. 40th Annual Meeting, National Mastitis Council (NMC). NMC, Madison, WI.

Seegers, H., C. Fourichon, and F. Beaudeau. 2003. Production effects related to mastitis and mastitis economics in dairy cattle herds. Vet. Res. 34:475-491.

Sharif, A., and G. Muhammad. 2008. Somatic cell count as an indicator of udder health status under modern dairy production: A review. Pakistan Vet. J. 28:194-200.

Shuster, D. E., R. J. Harmon, J. A. Jackson, and R. W. Hemken. 1991. Suppression of milk production during endotoxin-induced mastitis. J. Dairy Sci. 74:3763-3774.

Stocco, G., C. Cipolat-Gotet, A. Cecchinato, L. Calamari, and G. Bittante. 2015. Milk skimming, heating, acidification, lysozyme, and rennet affect the pattern, repeatability, and predictability of milk coagulation properties and of curd-firming model parameters: A case study of Grana Padano. J. Dairy Sci. 98:5052-5067.

Sturaro, E., E. Marchiori, G. Cocca, M. Penasa, M. Ramanzin, and G. Bittante. 2013. Characterization and sustainability of dairy systems in mountainous areas: Farm animal biodiversity, milk production and destination, and land use and landscape conservation. Livest. Sci. 158:157-168.

Summer, A., P. Franceschi, P. Formaggioni, and M. Malacarne. 2015. Influence of milk somatic cell content on Parmigiano-Reggiano cheese yield. J. Dairy Res. 82:222-227.

Suriyasathaporn, W., Y. H. Schukken, M. Nielen, and A. Brand. 2000. Low somatic cell count: A risk factor for subsequent clinical mastitis in a dairy herd. J. Dairy Sci. 83:1248-1255.

Swaisgood, H. E. 1982. Chemistry of milk proteins. Pages 1-52 in Development in Dairy Chemistry. P. F. Fox, ed. Appl. Sci. Publ., London, UK.

Toffanin, V., M. De Marchi, M. Penasa, D. Pretto, and M. Cassandro. 2012. Characterization of milk coagulation ability in bulk milk samples. Acta Agric. Slov. 100(Suppl. 3):93-98.

Urech, E., Z. Puhan, and M. Schällibaum. 1999. Changes in milk protein fraction as affected by subclinical mastitis. J. Dairy Sci. 82:2402-2411.
VanRaden, P. M. 2004. Invited review: Selection on net merit to improve lifetime profit. J. Dairy Sci. 87:3125-3131.

Vásquez, J. A., C. F. Novoa, and J. E. Carulla. 2014. Efecto del recuento de células somáticas sobre la aptitud quesera de la leche y la calidad fisicoquímica y sensorial del queso campesino. Rev. Fac. Med Vet Zoot. 61:171-185.

Verdi, R. J., D. M. Barbano, M. E. DellaValle, and G. F. Senyk. 1987. Variability in true protein. casein, nonprotein nitrogen, and proteolysis in high and low somatic cell milks. J. Dairy Sci. 70:230-242.

Vianna, P. C. B., G. Mazal, M. V. Santos, H. M. A. Bolini, and M. L. Gigante. 2008. Microbial and sensory changes throughout the ripening of Prato cheese made from milk with different levels of somatic cells. J. Dairy Sci. 91:1743-1750.

Viguier, C., S. Arora, N. Gilmartin, K. Welbeck, and R. O'Kennedy. 2009. Mastitis detection: current trends and future perspectives. Trends Biotechnol. 27:486-493.

Wellnitz, O., A. Baumert, M. Saudenowa, and R. M. Bruckmaier. 2010. Immune response of bovine milk somatic cells to endotoxin in healthy quarters with normal and very low cell counts. J. Dairy Res. 77:452-459.

Wellnitz, O., and R. M. Bruckmaier. 2012. The innate immune response of the bovine mammary gland to bacterial infection. Vet. J. 192:148-152.

Wickström, E., K. Persson-Waller, H. Lindmark-Mansson, K. Ostensson, and A. Sternesjo. 2009. Relationship between somatic cell count, polymorphonuclear leucocyte count and quality parameters in bovine bulk tank milk. J. Dairy Res. 76:195-201.

Wu, X. L., B. Heringstad, Y. M. Chang, G. De los Campos, and D. Gianola. 2007. Inferring relationships between somatic cell score and milk yield using simultaneous and recursive models. J. Dairy Sci. 90:3508-3521.

Yun, S. E., K. Ohmiya, and S. Shimizu. 1982. Role of phosphoryl group of $\beta$-casein in milk curdling. Agric. Biol. Chem. 46:1505-1511. 